NBER WORKING PAPER SERIES

\title{
POWER COUPLES: CHANGES IN THE \\ LOCATIONAL CHOICE OF THE \\ COLLEGE EDUCATED, 1940-1990
}

\author{
Dora L. Costa \\ Matthew E. Kahn \\ Working Paper 7109 \\ http://www.nber.org/papers/w7109 \\ NATIONAL BUREAU OF ECONOMIC RESEARCH \\ 1050 Massachusetts Avenue \\ Cambridge, MA 02138 \\ May 1999
}

We have benefited from the comments of Edward Glaeser, Claudia Goldin, Michael Kremer, Steve Levitt, Erzo Luttmer, Sendhil Mullainathan, Jörn-Steffen Pischke, James Poterba, and Peter Temin and of workshop participants at the University of Chicago, Boston College, Stanford, and the April 1999 NBER Labor Studies meeting. Dora Costa gratefully acknowledges the support of NIH grant AG12658. The views expressed herein are those of the authors and do not necessarily reflect the views of the National Bureau of Economic Research.

- 1999 by Dora L. Costa and Matthew E. Kahn. All rights reserved. Short sections of text, not to exceed two paragraphs, may be quoted without explicit permission provided that full credit, including ${ }^{\circ}$ notice, is given to the source. 
Power Couples: Changes in the Locational

Choice of the College Educated, 1940-1990

Dora L. Costa and Matthew E. Kahn

NBER Working Paper No. 7109

May 1999

JEL No. J1, R2

\begin{abstract}
The rise of the dual career household is a recent phenomenon spurred by the increase in married women's labor force participation rates and educational attainment rates. Compared to traditional households these households must solve a colocation problem. This paper documents trends in locational choice between large and small metropolitan areas and non-metropolitan areas by household type from 1940 to 1990 . We find that college educated couples are increasingly concentrated in large metropolitan areas and attribute at least half of this increase to the growing severity of the colocation problem. We also find that the relative returns for a college-educated couple of being in a large relative to a small city have increased across decades. Our results suggest that because skilled professionals are increasingly bundled with an equally skilled spouse, smaller cities may experience reduced inflows of human capital relative to the past and therefore become poorer. We examine how the relationship between rankings of university graduate programs and city size has changed between 1970 and 1990 to provide suggestive evidence on the importance of city size to firms' ability to attract the best workers.

Dora L. Costa

MIT

Department of Economics, E52

50 Memorial Drive

Cambridge, MA 02139

and NBER

Matthew E. Kahn

Columbia University

Department of Economics and International Affairs 420 W. 118th Street

New York, NY 10027

mkahn@mahler.econ.columbia.edu
\end{abstract}

costa@mit.edu 


\section{Introduction}

The rise of the dual career household is a recent phenomenon. In 1940, among couples aged 25 to 45 in which both husband and wife had at least a four year college education, only 18 percent of wives worked. ${ }^{1}$ Even women who had taken the same courses as men generally became school-teachers upon graduation, leaving the labor force because of marriage bars. Goldin (1997) describes the experience of these women as "first jobs then family." By 1970 the labor force participation rate of prime-aged college-educated wives married to college-educated men had risen to 39 percent, but the experience of these women was one of "first family then jobs" (Goldin 1997). Fifty-five percent of them had majored in such fields as education and nursing where few men got degrees and upon graduation had been tracked into traditionally female sectors, regardless of their majors. They left the labor force when their first child was born and only re-entered when all children were in school. By 1990, and to a lesser extent by 1980, prime-aged college-educated wives of college-educated men aspired to "career then family" or "career and family" (Goldin 1997). Their college majors were more similar to men's and in terms of labor supply parameters they began to resemble men as well, with small wage and income elasticities (Goldin 1990: 119-158). By 199074 percent of them were in the labor force.

As more households become dual career households, more of them face a colocation problem. Mincer (1978) and Sandell (1977) emphasized the "tied" worker effect where to maximize household income the secondary earner, traditionally the wife, might forgo matching with her best local labor market. Wives, however, may be increasingly unwilling to pay the economic costs of being the tied mover or stayer. As women's wages have risen relative to men's, as divorce rates have increased, and as the returns to experience have grown, the economic costs of

\footnotetext{
${ }^{1}$ All labor force participation numbers are estimated from the integrated public use census samples (Ruggles and Sobeck 1995).
} 
being the tied mover or stayer have risen. Forty-nine percent of women in two-career households interviewed in 1998 classified their careers as equal in importance to those of their husbands. ${ }^{2}$

Mincer (1978) argued that a possible outcome of the rise in dual career households and the resulting increased tension over the migration and location decision was the dissolution of the marriage. But, more optimistically, he also suggested that living in large metropolitan areas with diversified labor markets reduces the degree to which both husband and wife must compromise their individual gains from marriage. This strategy is well known to dual career households. A couple featured in an article in the Chicago Tribune (March 16, 1986) advised that living in a large metropolitan area was part of the success formula for a two-career family, "You need to select a large city that has an abundance of jobs and is a place where you'd like to spend a substantial amount of your life."3

The rise of the dual career household should lead to their greater concentration in large metropolitan areas. This paper documents trends in locational choice between large and small metropolitan areas and non-metropolitan areas since 1940 by household type. By comparing the locational decision of dual and non-dual career households and of dual career and single households we are able to identify whether dual career households are increasingly disproportionately located in large urban areas because these areas solve the colocation problem or whether their increasing concentration arises from another reason such as these areas offering higher returns to education or urban amenities being normal goods. We also document trends in wages by skill level and city size and trends in rents by city size to establish how the incentives of being in a

\footnotetext{
${ }^{2}$ Cited in USA Today, November 23, 1998.

${ }^{3}$ Mincer's intuition is also supported by suggestive, but inconclusive, evidence on the residence patterns of professionals. Frank (1978a) found that in 1970 professional women (a group likely to be married to professional men) had a higher probability of living in a large urban area than professional men (relatively few of whom would be married to professional women). Similarly, Marwell, Rosenfeld, and Spilerman (1979) showed that in 1969 married academic women were more likely than married academic men to live in large metropolitan areas.
} 
large city have changed for different households.

Our findings have implications for city growth. Large cities offer many more potential job matches. As skilled professionals are increasingly bundled with an equally skilled spouse, their demand for large cities will increase. The presence of large numbers of highly skilled workers within a concentrated geographic area may in turn provide positive growth externalities. ${ }^{4}$ Smaller cities, particularly those located in low amenity areas, may experience reduced inflows of human capital relative to the past and therefore become poorer. In 199855 percent of companies listed a spouse's employment as the biggest reason for employees declining a job relocation. ${ }^{5} \mathrm{We}$ present some suggestive evidence on the ability of firms in small cities to attract highly skilled workers by examing how the relationship between city size and the quality of university graduate programs has changed since 1970 .

Our findings also have implications for trends in household income inequality. Because the growth of large metropolitan areas enables professional couples to solve their joint location problem large this may magnify household income inequality.

\section{Household Locational Choice}

This paper studies household locational choice conditional on marital status. Consider first the migration decision in the absence of marriage. At a point in time an individual will calculate the expected lifetime present value of moving to a given city, accounting for wages (including the probability of finding a good match), rents, and amenities and move to the city that offers the

\footnotetext{
${ }^{4}$ This insight has been incorporated in theoretical models (Lucas 1988; Acemoglu 1996) and is supported by empirical investigations of the relationship between wages and average human capital (Heckman, Layne-Farrar, and Todd 1996; Rauch 1993) and local growth and average human capital within a city (Simon 1998; Glaeser, Shleifer, and Scheinkman 1995).

${ }^{5}$ Cited in USA Today, November 23, 1998.
} 
highest lifetime present value. That is, an individual will choose city $j$ such that

$$
\max _{j} G\left(w_{j}, R_{j}, A_{j}\right)
$$

where $w_{j}, R_{j}$, and $A_{j}$ are wages, rents, and amenity values in city $j$. Although a household may later choose to locate to a different sized city, the initial decision on what size metropolitan area to move to will both determine current earnings and be an investment in future earnings (Sjaastad 1962).

Now consider how marriage affects the locational decision. In a static model a couple marries and then decides what city to live in. Assuming that marital matching occurs on love not ambition, the husband's best match is not necessarily the wife's best match. The couple therefore has a colocation problem. ${ }^{6}$ One resolution of the colocation problem is for one spouse to make a transfer to other. The couple therefore maximizes their joint expected present value of moving to a given city $j$

$$
\max _{j}\left(G_{1}+G_{2}\right)
$$

This joint expected present value may be less than the combined maximum expected present values that a couple living in separate cities could obtain, that is,

$$
\max _{j} G_{1}+\max _{j} G_{2}
$$

In a dynamic model, forward looking singles would forsee future colocation problems and move to cities that both offer rich marriage markets and that minimize the differential between the

\footnotetext{
${ }^{6}$ We recognize that if the colocation problem is severe enough certain marriages never take place. For a survey of the gains to marriage and marriage formation see Weiss 1997. See also Becker (1991).
} 
maximum joint expected present value and the combined maximum expected present value that a couple living in separate cities could obtain (3-2). ${ }^{7}$

Note that in both the dynamic and static models the colocation problem arises because of bundling. If individuals could live in one city and work in another then this would not be a problem. Although for some individuals commuting is an option, it is costly. If neither commuting nor transfers within the marriage are an option then the marriage may dissolve.

Large cities mitigate the colocation problem. Large metropolitan areas offer couples in which both husband and wife are pursuing specialized, professional careers a much larger market for their skills and thus make it more likely that both husband and wife can find jobs commensurate with their skills in the same location. ${ }^{8}$ Because large cities offer more potential job matches, the probability of drawing a good initial match is higher. The probability of drawing good subsequent matches is also higher and this increased job mobility will lead to greater lifetime wage growth (Topel and Ward 1992). Furthermore, if the initial match was a poor one, then the probability of drawing a good match on the second try will be higher than in a smaller city. A spouse who knows that the other spouse has these options in a large city can therefore make firm specific career investments. The financial sacrifice to being in a large city is therefore likely to be smaller.

The colocation problem is likely to be most severe among highly educated couples because of their specialized skills. Of course, there may be other reasons that such couples prefer to live in larger cities. Because any single individual can find a better match in a large city

\footnotetext{
${ }^{7}$ An alternative model would be that singles migrate to a city, marry, and remain there out of inertia. This model assumes that couples do not take advantage of arbitrage opportunities. But, mobility among married men is high. Among married, native-born men age 30 to 45 in 1940, 40 percent lived in a state other than their state of birth and 6 percent had moved to a different state and 5 percent to another metropolitan area within the last 5 years. The figures for their 1990 counterparts were 83 percent, 32 percent, and 30 percent, respectively.

Despite the high mobility of married couples, most migration is within the same city size category. This is true for couples married within the last five years as well.

${ }^{8}$ Baumgardner (1988) documents the greater specialization among physicians found in large cities. See Kim (1989) for a theoretical model of labor specialization and the size of the labor market.
} 
the returns to education are greater in larger cities. Larger metropolitan areas also offer such amenities enjoyed by the highly educated as museums and theaters. The cost of living in a large metropolitan area is higher rents and such urban disamenities as crime and pollution. ${ }^{9}$ However, since 1970 these disamenity costs have been falling (Glaeser 1998; Kahn 1997). Higher returns to education and urban amenities will therefore make large cities attractive to households without a colocation problem. Such households include those in which only one spouse is highly educated, single individuals (who may also value cities for their marriage markets), and households in which the wife does not work. Households in which the wife has a strong attachment to the labor force will find large cities attractive because both husband and wife are more likely to find a good job match in such a city. City size may determine the wife's propensity to work. In a city in which the wife can find a good job match the substitution effect of the wife's wages is greater thus increasing her probability of working, but the income effect from the husband's wages counters the substitution effect. ${ }^{10}$

We view all households as one of 7 types: "power" couples in which both spouses have a college education, "part-power" couples in which only one spouse has a college education, "low-power" couples in which neither spouse has a college education, and single households of college educated men, college educated women, non-college educated men, and non-college educated women. ${ }^{11}$ Each household will consider the rents, wages, and amenities offered by each city size. Unlike two single individuals, a married couple can economize on rents. At a point in time a spatial equilibrium is an allocation of households across cities such that no household can

\footnotetext{
${ }^{9}$ Of course, within a given metropolitan area there is Tiebout sorting such that households can choose their communities within the metropolitan area and match their tastes with the taxes and services these localities provide.

${ }^{10}$ In aggregate, own wage effects dominate cross effects between husband and wife in accounting for changes in married women's participation rates (Juhn and Murphy 1997; Mincer 1962).

${ }^{11}$ Although two college-educated spouses do not make a dual career household, college education of both spouses is nonetheless a necessary condition. We will later compare the locational choice of couples in which the wife is in a traditionally female occupation, with that of couples in which the wife is not in such an occupation.
} 
Table 1: Percentage of Marriages by Couple Type

\begin{tabular}{lrrrrr} 
& 1940 & 1960 & 1970 & 1980 & 1990 \\
\hline Low-Power & 90.1 & 83.5 & 78.2 & 69.8 & 64.0 \\
Part-Power & 6.9 & 11.8 & 14.3 & 17.7 & 19.7 \\
Power & 2.2 & 4.7 & 7.5 & 12.5 & 16.2 \\
\hline
\end{tabular}

Note. A power couple is defined as one in which both husband and wife have had at least 4 years of college, a part-power couple as one in which only one spouse has had at least 4 years of college, and a low-power couple as one in which neither spouse has had at least 4 years of college. All numbers are estimated from the integrated public use sample (Ruggles and Sobek 1995) and are for households in which the husband was age $25-45$.

raise its expected present value of utility by moving and no firm can raise its expected profits by moving. ${ }^{12}$

\subsection{Trends: Power Couple Formation}

The proportion of married couples in which both husband and wife have at least a college education has increased from 2 percent in 1940 to 16 percent in 1990 (see Table 1). The percentage increase in the proportion of couples in which only one spouse has a college education has been smaller, rising from 7 percent in 1940 to 22 percent in $1990 .{ }^{13}$ These increases in the relative proportion of power couples arose largely from greater college attendance rates, which in turn were spurred both by the growth of public universities and of high schools and by the rising economic returns to college. ${ }^{14}$

Rising wives' labor force participation rates, increases that have been larger among

\footnotetext{
${ }^{12}$ For a fuller discussion of the cross-sectional compensating spatial equilibrium see Roback (1982), Blomquist, Berger, and Hoehn (1988) and Gyourko and Tracy (1991).

${ }^{13}$ Among part-power couples in 1940, the husband was the college-educated spouse in 76 percent of all cases. In 1990 he was the college-educated spouse in 63 percent of all cases.

${ }^{14}$ Although prime-aged women in 1970 gained little direct economic return from their degrees, their indirect gains were considerable because for them college was a marriage market (Goldin 1992). Additional factors increasing the percentage of power couples include increased assortative mating (Pencavel 1998; Mare 1991; Goldin 1992).
} 
Table 2: Employment and Fertility Trends by Education of Couple

\begin{tabular}{lccccc} 
& 1940 & 1960 & 1970 & 1980 & 1990 \\
\hline Wife Works (\%) & & & & & \\
Low-Power & 16.9 & 29.0 & 38.5 & 53.6 & 65.6 \\
Part-Power & 15.9 & 25.1 & 28.9 & 57.9 & 71.3 \\
Power & 18.2 & 31.7 & 39.1 & 64.9 & 74.3 \\
Have Child (\%) & & & & & \\
Low-Power & 74.3 & 87.5 & 88.5 & 85.5 & 83.3 \\
Part-Power & 65.8 & 86.4 & 87.2 & 77.6 & 76.2 \\
Power & 64.0 & 83.5 & 79.3 & 70.2 & 71.0 \\
Wife Works and in & & & & & \\
Traditionally Female Job (\%) & & & & & \\
Power & 69.9 & 71.2 & 73.5 & 60.0 & 47.0 \\
\hline
\end{tabular}

Note. A power couple is defined as one in which both husband and wife have had at least 4 years of college, a part-power couple as one in which only one spouse has had at least 4 years of college, and a low-power couple as one in which neither spouse has had at least 4 years of college. All couples are restricted to those in which the husband was between 25 and 45 years of age. All numbers are estimated from the integrated public use sample (Ruggles and Sobek 1995).

power couples than among low power couples, have made power couples true dual career households and increased the fraction of power couples with a colocation problem (see Table 2). ${ }^{15}$ The labor force participation rate of power couple wives rose from 18 to 74 percent between 1940 and 1990, whereas the increase for low-power wives was from 17 to 66 percent. The proportion of working power couple wives in such traditional female occupations as school teacher, nurse, librarian, or social worker fell from 70 to 47 percent between 1940 and 1990. The percentage with at least one child rose to 84 percent in 1960 from 64 percent in 1940, but by 1980 had fallen to 70 percent. ${ }^{16}$ These increases in wives' labor force participation rates and their entry into

\footnotetext{
${ }^{15}$ Some of the growth in wives' labor force participation rates may arise from the increased propensity of women who aspire to careers to marry (Goldin 1997).

${ }^{16}$ When we stratify the data by city size we find that married women in large cities have lower fertility rates. For example, in 194076 percent of women in non-metropolitan areas had a child compared to 72 percent in metropolitan areas. In 199084 percent of women in non-metropolitan areas had a child compared to 80 percent in small
} 
traditionally male jobs have increased the costs to a household of picking a city size in which the wife earns relatively little. Furthermore, falling transport costs have lowered the price of moving to a city distant from family members.

\subsection{Trends: Location}

We predict that the major social changes of the last decades have affected the location decision of households as follows:

- Power couples will be increasingly concentrated in large cities because large cities solve the colocation problem; because they can obtain higher returns to their education in larger cities and, unlike single people, they can economize on rents; and finally, because city amenities are normal goods.

- We should observe this increasing concentration of power couples relative to part-power and low power couples, particularly between 1970 and 1980 or 1990 because women in 1980 and 1990 were more similar to men in terms of labor force attachment than women in 1970 or earlier.

- Married women's labor force participation should be higher in large cities, particularly in the last decades.

- If a wife never works or if her occupation is the same as her husband's the couple may not need the diversified market offered by a large metropolitan area.

metropolitan areas and 77 percent in large metropolitan areas. One plausible explanation is that women in large cities substitute towards market rather than non-market activities. Women in smaller cities may also face a lower price of high quality child care. Hofferth and Wissoker (1992) find that the child to staff ratio in day care centers is higher in metropolitan than in non-metropolitan areas. 
Table 3: Costs and Benefits of Living in a Large City for Power and Part-Power Couples at a Point in Time

\begin{tabular}{llrrrr} 
& \multicolumn{2}{c}{$\begin{array}{c}\text { Returns to } \\
\text { Education }\end{array}$} & Rent & Amenities & Colocation \\
\hline 1 & Wife Works and Power & ++ & - & ++ & + \\
2 & Wife Works and Part-Power & + & - & + & 0 \\
3 & Double Difference (1-2) & + & 0 & + & + \\
4 & Wife Does Not Work and Power & ++ & - & ++ & 0 \\
5 & Wife Does Not Work and Part-Power & + & - & + & 0 \\
6 & Double Difference (4-5) & + & 0 & + & 0 \\
7 & Triple Difference (3-6) & 0 & 0 & 0 & + \\
\hline
\end{tabular}

Note. If amenity values are assumed to be the same for power and part-power couples then the double and triple difference are equivalent. If wives are highly responsive to income and substitution effects then only a double difference regardless of the wife's labor force status can be estimated.

We establish whether the proportion of power couples in large cities is rising because of the colocation problem or because the returns to education are rising in large cities and disamenity costs are falling by using part-power couples and single households as a control group for power couples. If the latter factors are the primary explanation then we should observe an increasing proportion of part-power couples and single households in large metropolitan areas as well.

Table 3 provides a schematic illustration of the costs and benfits of being in a large city for power and part-power couples at a point in time. ${ }^{17}$ Power couples may be in large cities because of the colocation problem, increasing returns to education for both husband and wife (or a better probability of finding a job match regardless of current labor force participation status), and amenities. In contrast part-power couples may be in large cities because of increasing returns

\footnotetext{
${ }^{17}$ This tables assumes that all items such as amenities enter the utility function linearly and that there is no sorting such that power individuals married to power individuals earn higher returns to their education or value city amenities differently than power individuals married to low-power individuals.
} 
Table 4: Costs and Benefits of Living in Large City for Power and Low-Power Couples and Two Power and Coincidental Couples at a Point in Time

\begin{tabular}{llrrrr} 
& Returns to & & \\
& & Education & Rent & Amenities & Colocation \\
\hline 1 & Power Couple & ++ & - & + & + \\
2 & Power Coincidental Couple & ++ & -- & ++ & 0 \\
3 & Double Difference (1-2) & 0 & - & + & + \\
4 & Low-Power Couple & 0 & - & + & 0 \\
5 & Low-Power Coincidental Couple & 0 & -- & ++ & 0 \\
6 & Double Difference (4-5) & 0 & - & + & 0 \\
7 & Triple Difference (3-6) & 0 & 0 & 0 & + \\
\hline
\end{tabular}

Note. Note that amenities are assumed to differ by couple type only because large cities offer goods attractive to singles such as a marriage market.

to education to one spouse or amenities. The double difference estimate,

$$
\Delta_{90-40}^{P}-\Delta_{90-40}^{P P}
$$

where $\Delta_{90-40}^{P}$ is the change in the proportion of power couples in a large city between 1990 and 1940 and $\Delta_{90-40}^{P P}$ is the change in the proportion of part-power couples, therefore captures the differential trend in returns to education, amenities, and colocation. The triple difference (estimated from double differences conditional on the wife's labor force participation status),

$$
\left[\Delta_{90-40}^{P, W W}-\Delta_{90-40}^{P P, W W}\right]-\left[\Delta_{90-40}^{P, N W}-\Delta_{90-40}^{P P, N W}\right]
$$

where $W W$ indicates that the wife works and $N W$ that she does not, measures the impact of changes in the severity of the colocation problem. Note that the triple difference assumes that income and substitution effects are small and that there are two types of wives: those who work and those who do not. If income and substitution effects are large and if amenity values are 
the same for power and part-power couples, the double difference in Equation 4 will be a better estimate of the impact of the colocation problem than the triple difference in Equation 5.

Now consider the comparison between power and low power couples and two single individuals, one male and one female, coincidentally living in a large city. Single individuals will have no colocation problem but will have different amenity values because they value large cities as marriage markets (see Table 4). The double difference between power couples and coincidental power couples,

$$
\Delta_{90-40}^{P}-\Delta_{90-40}^{S P},
$$

where $S P$ indicates two power singles, therefore measures the differential trend in rents (singles pay two rents rather than one), amenities, and colocation. The double difference between lowpower couples and coincidental low-power couples,

$$
\Delta_{90-40}^{L P}-\Delta_{90-40}^{S L P},
$$

where $L P$ indicates a low-power couple and $S L P$ two low-power singles, measures the differential trend in rents and amenities. Assuming that amenity values are the same for power and low-power individuals, the triple difference,

$$
\left[\Delta_{90-40}^{P}-\Delta_{90-40}^{S P}\right]-\left[\Delta_{90-40}^{L P}-\Delta_{90-40}^{S L P}\right]
$$

measures the extent of the change in the proportion of power couples in large cities that arises from an increasingly severe colocation problem. ${ }^{18}$

\footnotetext{
${ }^{18}$ This will of course be true only if items such as amenities enter the utility function linearly and if singles differ from married individuals only in their marital status.
} 


\section{Data}

We examine long-term trends in locational choice using the 1940 and 1970-1990 censuses of population and housing. ${ }^{19}$ For each person we observe marital status, age, sex, race, education, labor force status, occupation, and metropolitan area. We restrict the sample to couples in which the husband was 25 to 45 years of age because we do not wish to examine couples at the end of their careers.

We use city population size as a proxy for the potential number of job matches. We classify the suburbs of central cities as part of the labor market of the central city (e.g. Westchester county is classified as part of the New York City labor market). Because the Census Bureau used different definitions and taxonomies to describe the geography of metropolitan areas in our four census years, we experimented with different definitions of what constituted a particular metropolitan area. For example, the 1940 and 1970 censuses did not include Santa Rosa as part of the San Francisco Bay Area whereas those of 1980 and 1990 did. We therefore created two different definitions of the San Francisco Bay Area. One was based purely upon the 1970 definition and excluded Santa Rosa. The second definition excluded Santa Rosa in 1970 (when it was still a small, rural town) but included it in 1980 and 1990 (when it had become a suburb). ${ }^{20}$ Although our results were not affected by the definition that we used, we present results using the second definition because we want to allow for the expansion of metropolitan areas into farmland at the periphery (Brueckner and Fansler 1982). The large price elasticity of housing (Topel and Rosen 1988) suggests that this conversion can be rapid.

We create 5 city size categories: non-metropolitan, or, if metropolitan, one of four

\footnotetext{
${ }^{19}$ We use the integrated public use micro samples available at http://www.hist.umn.edu/ ipums. Earlier censuses did not identify education. We cannot use the 1950 census because education is known only for the sample line person. We cannot use the 1960 census because metropolitan area is not identified.

${ }^{20}$ Jaeger et al. (1998) show how to construct consistent definitions of metropolitan areas from 1970 to 1990.
} 
classes such that each one contains 25 percent of the population that is in all metropolitan areas. ${ }^{21}$ Note that the definition of a metropolitan area differed across years. The 1940 and 1950 censuses identified metropolitan areas if the population in these areas was at least 100,000 in 1980 and the 1980 and 1990 censuses identified metropolitan areas with populations of at least 100,000 in the census year. The 1970 census identified metropolitan areas with populations of at least 250,000 in 1970. We may therefore underestimate the extent of the move away from non-metropolitan to metropolitan areas between 1940 and 1970 and between 1970 and 1980.

We predict that the concentration of power couples will differ across non-metropolitan areas and areas in the bottom and top fiftieth percentile. However, this concentration may not necessarily be higher in larger cities within the upper fiftieth percentile. For some professionals, the New York city area may provide a thinner market than the Boston area. ${ }^{22}$ We do not classify cities based on which industries are over-represented. We do not observe the industry of nonworking wives. Furthermore, with the exception of Washington DC, there were relatively few differences in cities in the top fiftieth percentile by broad industry category.

We use information on what city size category a couple chooses to live in and whether the wife works to create 10 groups, one each for wife's labor force participation status and the city size category. We then estimate a multinomial logit of the choice of wife's labor force participation and city size as a function of the age, race, and educational attainment of the husband and wife.

\footnotetext{
${ }^{21}$ Cities in the top quartile in 1940 were Chicago and New York; in 1970 Chicago, Los Angeles, and New York; in 1980 Chicago, Los Angeles, New York, Philadelphia, and San Francisco; in 1990 Chicago, Los Angeles, New York, Philadelphia, and San Francisco. Cities in the second top quartile in 1940 were Boston, Cleveland, Detroit, Los Angeles, Philadelphia, Pittsburgh, St. Louis, and San Francisco; in 1970 Boston, Cleveland, Dallas, Detroit, Houston, Philadelphia, Pittsburgh, San Francisco, and Washington DC; in 1980 Atlanta, Baltimore, Boston, Cincinnati, Cleveland, Dallas, Denver, Detroit, Houston, Miami, Minneapolis, Pittsburgh, St. Louis, San Diego, Seattle, and Washington DC; in 1990 Atlanta, Baltimore, Boston, Cincinnati, Cleveland, Dallas, Denver, Detroit, Houston, Miami, Minneapolis, Phoenix, Pittsburgh, St. Louis, San Diego, Seattle, and Washington DC. Changes within these categories are minimal when we use the 1970 definitions. Under these definitions Philadelphia was in the top quartile in 1940 and Detroit in 1980 and Tampa-St. Petersburg was in the second highest quartile.

${ }^{22}$ Classifying city size by the number of college graduates rather than of people should not yield different results. The correlation between population size and number of college graduates in 1990 was 0.98 .
} 
Thus, assuming that $P_{s, w w}$ is the probability of being in one of 5 city sizes $s$ and $w w$ is an indicator equal to one if the wife works, we estimate

$$
\log \left(\frac{P_{s, w w}}{P_{s=5, w w=1}}\right)=\beta^{\prime} X
$$

for $s=1$ to 4 and $w w=0,1$ and $s=5$ and $w w=0$. We calculate robust standard errors clustering on metropolitan areas (or on the state in the case of non-metropolitan areas). Finally, we predict the choice of location and wife's labor force participation, $P_{s, w w}$, for a white household in which the husband is 35 years of age conditional on being a power, part-power, or low-power couple. ${ }^{23}$ For single individuals we estimate similar multinomial logit specifications (separately for men and women) except that we control only for own characteristics. ${ }^{24}$ We then predict locational choice for single, white individuals age 35 conditional on being a power or a low-power individual. We use our predicted probabilities from our specification for couples to estimate the double and triple differences in Equations 4 and 5. We use our predicted probabilities from our specification for couples together with those from our specification for singles to estimate the triple difference in Equation 8.

\section{Results: Locational Choice}

Table 5 shows the predicted probabilities, conditional on being a power, part-power, or low-power couple, of locational choice across city sizes and the wife's labor force participation status for

\footnotetext{
${ }^{23}$ Estimates of bivariate probits on whether the wife works and whether the couple lives in a large city suggested little correlation across the error terms of these two equations.

${ }^{24}$ Because never married singles who were household heads were generally in the labor force we obtained similar estimates regardless of whether our dependent variable consisted of 10 locational choice-labor force status categories or 5 locational choice categories. The results that we present are derived from a multinomial logit model with 10 locational choice-labor force status categories, but we present only aggregated results.
} 
a white couple in which the husband was 35 years old. ${ }^{25}$ Note that power couples are leaving non-metropolitan areas and moving to the largest metropolitan areas. In 194030 percent were in non-metropolitan areas whereas in 199013 percent were. In 194040 percent were in the largest metropolitan areas whereas in 199050 percent were. The largest changes were between 1970 and 1980 when the share in non-metropolitan areas declined from 30 to 17 percent. The timing of this decline coincides with the entry of women who aspired to "career then family" into the labor force.

Power couples are increasingly concentrating in large metropolitan areas relative to partpower or low-power couples (see Figure 1). Between 1940 and 1990 the predicted proportion of low power couples located in non-metropolitan areas fell only from 34 percent to 28 percent and their share in the largest metropolitan areas barely changed from 33 to 32 percent. The predicted percentage of part power couples in the largest metropolitan areas rose from 38 to 42 percent.

Table 5 also shows that for power couples the predicted labor force participation rate of women rose more sharply in larger than in smaller metropolitan areas and in non-metropolitan areas. Between 1940 and 1990 the predicted proportion of power couples in which the wife works located in large cities rose from 8 to 35 percent. The largest change was between 1970 and 1980 when the proportion rose from 12 to 28 percent. In contrast, the predicted percentage of power couples in which the wife works located in non-metropolitan areas rose only from 4 to 10 percent.

The predicted proportion of working power couples in major cities grew relative to working part or low-power couples. Between 1940 and 1990 this figure increased only from 6 to 27 percent for part-power couples and from 5 to 21 percent for low power couples. Between 1970 and 1980 when the predicted proportion of working couples in major cities more than doubled

\footnotetext{
${ }^{25}$ Although we used 4 metropolitan area groupings in our estimation we present only aggregated predictions. The concentration of power couples was greater by city size in all years, except for 1990, when it was lower in the highest city size category than in the next highest.
} 
Table 5: Predicted Probabilities of Locational Choice and Wife's Labor Force Participation (LFP) Status Conditional on Household Type

\begin{tabular}{|c|c|c|c|c|}
\hline & 1940 & 1970 & 1980 & 1990 \\
\hline \multicolumn{5}{|l|}{ Conditional on Low-Power } \\
\hline \multirow[t]{2}{*}{ Non-metropolitan area, LFP $=0$} & 0.329 & 0.257 & 0.147 & 0.104 \\
\hline & $(0.003)$ & $(0.002)$ & $(0.002)$ & $(0.002)$ \\
\hline \multirow[t]{2}{*}{ Non-metropolitan area, LFP=1 } & 0.012 & 0.157 & 0.149 & 0.179 \\
\hline & $(0.001)$ & $(0.001)$ & $(0.002)$ & $(0.002)$ \\
\hline \multirow[t]{2}{*}{ Small metropolitan area, $\mathrm{LFP}=0$} & 0.248 & 0.196 & 0.176 & 0.130 \\
\hline & $(0.003)$ & $(0.002)$ & $(0.002)$ & $(0.002)$ \\
\hline \multirow[t]{2}{*}{ Small metropolitan area, $\mathrm{LFP}=1$} & 0.049 & 0.112 & 0.194 & 0.256 \\
\hline & $(0.001)$ & $(0.001)$ & $(0.002)$ & $(0.002)$ \\
\hline \multirow[t]{2}{*}{ Large metropolitan area, LFP $=0$} & 0.282 & 0.190 & 0.169 & 0.127 \\
\hline & $(0.003)$ & $(0.002)$ & $(0.002)$ & $(0.002)$ \\
\hline \multirow[t]{2}{*}{ Large metropolitan area, $\mathrm{LFP}=1$} & 0.051 & 0.089 & 0.165 & 0.205 \\
\hline & $(0.001)$ & $(0.010)$ & $(0.002)$ & $(0.002)$ \\
\hline \multicolumn{5}{|l|}{ Conditional on Part-Power } \\
\hline \multirow[t]{2}{*}{ Non-metropolitan area, LFP $=0$} & 0.259 & 0.230 & 0.089 & 0.053 \\
\hline & $(0.008)$ & $(0.003)$ & $(0.002)$ & $(0.002)$ \\
\hline \multirow[t]{2}{*}{ Non-metropolitan area, LFP $=1$} & 0.024 & 0.118 & 0.120 & 0.133 \\
\hline & $(0.004)$ & $(0.002)$ & $(0.003)$ & $(0.003)$ \\
\hline \multirow[t]{2}{*}{ Small metropolitan area, $\mathrm{LFP}=0$} & 0.272 & 0.195 & 0.174 & 0.122 \\
\hline & $(0.009)$ & $(0.003)$ & $(0.003)$ & $(0.003)$ \\
\hline \multirow[t]{2}{*}{ Small metropolitan area, $\mathrm{LFP}=1$} & 0.053 & 0.100 & 0.206 & 0.272 \\
\hline & $(0.004)$ & $(0.002)$ & $(0.004)$ & $(0.003)$ \\
\hline \multirow[t]{2}{*}{ Large metropolitan area, $\mathrm{LFP}=0$} & 0.324 & 0.265 & 0.199 & 0.149 \\
\hline & $(0.009)$ & $(0.003)$ & $(0.003)$ & $(0.003)$ \\
\hline \multirow[t]{2}{*}{ Large metropolitan area, $\mathrm{LFP}=1$} & 0.059 & 0.092 & 0.212 & 0.270 \\
\hline & $(0.005)$ & $(0.002)$ & $(0.003)$ & $(0.003)$ \\
\hline \multicolumn{5}{|l|}{ Conditional on Power } \\
\hline \multirow[t]{2}{*}{ Non-metropolitan area, $\mathrm{LFP}=0$} & 0.250 & 0.183 & 0.052 & 0.027 \\
\hline & $(0.001)$ & $(0.003)$ & $(0.002)$ & $(0.001)$ \\
\hline \multirow[t]{2}{*}{ Non-metropolitan area, LFP $=1$} & 0.035 & 0.113 & 0.120 & 0.101 \\
\hline & $(0.004)$ & $(0.003)$ & $(0.003)$ & $(0.002)$ \\
\hline \multirow[t]{2}{*}{ Small metropolitan area, $\mathrm{LFP}=0$} & 0.260 & 0.174 & 0.134 & 0.095 \\
\hline & $(0.012)$ & $(0.004)$ & $(0.003)$ & $(0.002)$ \\
\hline \multirow[t]{2}{*}{ Small metropolitan area, $\mathrm{LFP}=1$} & 0.053 & 0.107 & 0.235 & 0.281 \\
\hline & $(0.006)$ & $(0.003)$ & $(0.004)$ & $(0.004)$ \\
\hline \multirow[t]{2}{*}{ Large metropolitan area, $\mathrm{LFP}=0$} & 0.313 & 0.316 & 0.178 & 0.144 \\
\hline & $(0.013)$ & $(0.004)$ & $(0.004)$ & $(0.003)$ \\
\hline \multirow[t]{2}{*}{ Large metropolitan area, LFP $=1$} & 0.087 & 0.107 & 0.282 & 0.353 \\
\hline & $(0.008)$ & $(0.003)$ & $(0.004)$ & $(0.004)$ \\
\hline
\end{tabular}

Note. All predictions are from a multinomial logit model (see text for details). The predictions are for a white couple in which the husband was 35 years old. Robust standard errors are in parentheses. Conditional on couple type, the columns should sum to one. 
Figure 1: Predicted Probability of Being in a Large City for Power Couples, Part-Power Couples, and Low-Power Couples

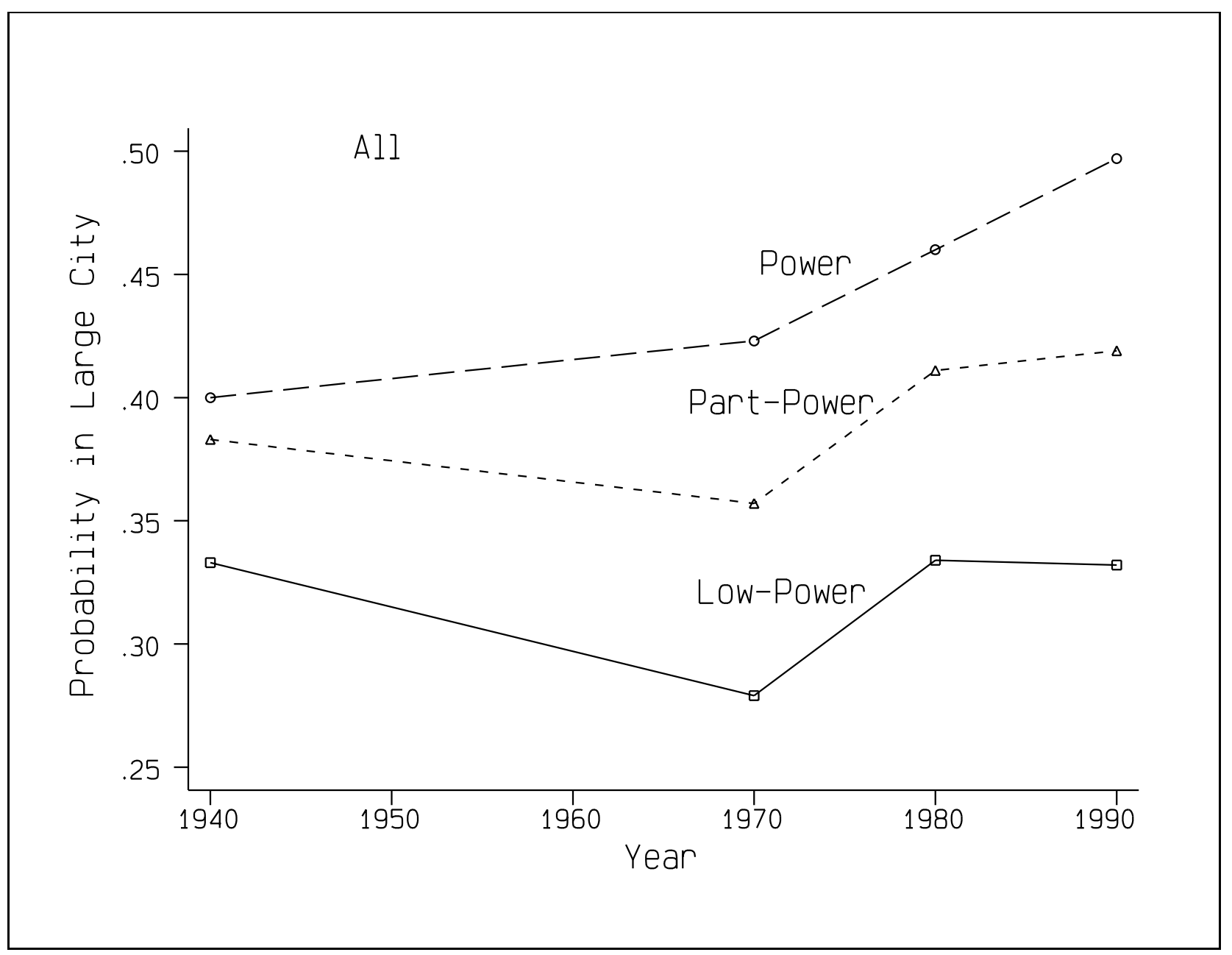

Note. Predicted probabilities are from Table 5. See table notes for estimation details. 
for power couples it only doubled for part-power couples and less than doubled for low-power couples.

Table 5 shows that when the wife does not work the predicted locational choice of partpower and power couples looks very similar. In 1990 the predicted proportion of couples living in the largest cities and in which the wife does not work was 15 percent for part-power couples and 14 percent for power couples whereas the respective figures for part-power and power couples in which the wife works were 27 and 35 percent. Our results suggest that the concentration of working power couples in large cities does not depend upon their having additional income to pay large city rents, but rather that it depends upon the colocation problem. Because smaller cities offer lower rents part-power and power couples in which the wife does not work may gain a relative pecuniary advantage in smaller metropolitan areas.

Table 6 explicitly presents the predicted differential trend in power couple relative to part-power and low-power locational choice. It shows $\Delta_{90-40}^{P}-\Delta_{90-40}^{P P}$ and $\Delta_{90-40}^{P}-\Delta_{90-40}^{L P}$ where $\Delta_{90-40}$ indicates the difference in the fraction of power $(P)$, part-power $(P P)$, or lowpower $(L P)$ couples locating in a particular city size between 1990 and 1940. If part-power or low-power couples are subject to the same changes in amenity values and wages as power couples but no colocation problem then the double difference for large cities shows the increase in concentration of power couples explained by a worsening of the colocation problem. Table 6 also shows estimates of this double difference by wife's labor force participation status. These double difference estimates are then used to estimate a triple difference, e.g. $\left[\Delta_{90-40}^{P, W W}-\Delta_{90-40}^{P P, W W}\right]-$ $\left[\Delta_{90-40}^{P, W N W}-\Delta_{90-40}^{P P, W N W}\right]$, to account for the differential effect of changes in amenity values and of returns to education on power and part-power couples and on couples in which the wife works and those in which the wife does not work. Note that the double difference estimate using part-power couples as a control group suggests that the fraction of power couples living in large cities because of the diverse labor markets that large cities offer has risen by 0.06 whereas the triple difference 
suggests that it has risen by 0.05 . Thus up to 52 to 62 percent of the 0.097 predicted increase in the proportion of power couples living in large cities can be attributed to the growing severity of the colocation problem. Both the double and triple difference show no change in the propensity of power couples to live in the smaller metropolitan areas and a decline of 0.18 to 0.23 in their propensity to live in non-metropolitan areas.

As we will show in the remainder of this section, our finding that the colocation problem explains at least 52 to 62 percent of the predicted increased concentration of power couples in large cities from 1940 to 1990 stands the test of using other controls as well. These include comparing power and part-power couples on the basis of whether the wife is in a traditionally female occupation. They also include using two never married individuals of the same educational attainment as controls. ${ }^{26}$ We therefore now turn to multinomial logit models of locational choice for never married men and women to obtain their predicted locational choice probabilities.

We estimate separate multinomial logit models of locational choice for never married men and women who were household heads and present their predicted locational choice probabilities conditional on their being power or low-power individuals (see Table 7). The proportion of never married men with less than a college education living in large cities rose from 38 to 48 percent whereas the proportion with a college education rose only from 46 to 52 percent. Among women these increases were larger, with the percentage with less than a college education rising from 38 to 50 percent and that with at least a college education rising from 40 to 49 percent. The proportion of never married men and women with at least a college education living in smaller metropolitan areas rose, with greater increases for men, and the proportion living in non-metropolitan areas fell sharply.

\footnotetext{
${ }^{26}$ We use never married individuals as controls rather than non-married individuals because the divorced with children may have stronger locational ties and because the divorced may have invested in their location because of an original colocation problem.
} 
Table 6: Double and Triple Difference Estimates of Propensity to Live in Given Size City, 1940-1990, Using Couple Type as Control Group

City Size

Large Medium Non-metropolitan

\begin{tabular}{crrr}
\hline Double Differences & & & \\
All Couples & & & \\
$\Delta_{90-40}^{P}-\Delta_{90-40}^{P P}$ & 0.061 & -0.006 & -0.057 \\
& $(0.020)$ & $(0.018)$ & $(0.011)$ \\
$\Delta_{90-40}^{P}-\Delta_{90-40}^{L P}$ & 0.098 & -0.026 & -0.096 \\
& $(0.017)$ & $(0.016)$ & $(0.007)$ \\
Wife Works & & & \\
$\Delta_{90-40}^{P}-\Delta_{90-40}^{P P}$ & 0.055 & 0.009 & -0.043 \\
& $(0.011)$ & $(0.009)$ & $(0.007)$ \\
$\Delta_{90-40}^{P}-\Delta_{90-40}^{L P}$ & 0.057 & 0.021 & -0.101 \\
& $(0.009)$ & $(0.008)$ & $(0.005)$ \\
Wife Does Not Work & & & -0.017 \\
$\Delta_{90-40}^{P}-\Delta_{90-40}^{P P}$ & 0.006 & -0.015 & $(0.008)$ \\
$\Delta_{90-40}^{P}-\Delta_{90-40}^{L P}$ & $(0.016)$ & $(0.015)$ & 0.002 \\
& -0.014 & -0.047 & $(0.004)$ \\
Triple Difference & $(0.014)$ & $(0.013)$ & \\
{$\left[\Delta_{90-40}^{P}-\Delta_{90-40}^{P P}\right]$ Working Wife -} & & & 0.026 \\
{$\left[\Delta_{90-40}^{P}-\Delta_{90-40}^{P P}\right]$ Non-Working Wife } & 0.049 & 0.024 & $(0.011)$ \\
{$\left[\Delta_{90-40}^{P}-\Delta_{90-40}^{L P}\right]_{\text {Working Wife }}-$} & $(0.019)$ & $(0.017)$ & -0.103 \\
{$\left[\Delta_{90-40}^{P}-\Delta_{90-40}^{L P}\right]$ Non-Working Wife } & 0.071 & 0.068 & $(0.006)$ \\
\hline & $(0.017)$ & $(0.015)$ &
\end{tabular}

Note. $\Delta_{90-40}^{P}, \Delta_{90-40}^{P P}$, and $\Delta_{90-40}^{L P}$ represent the change from 1940 to 1990 of the probability of being in a given sized metropolitan area for power, part-power, and low-power couples respectively. Standard errors are in parentheses. The double differences use part-power and low-power couples as control groups for power couples both for the whole sample and for the sample conditional on wife's labor force participation. The triple differences are the differences between the double differences conditional on wife's labor force participation. 
Table 7: Predicted Probabilities of Locational Choice, Never Married Men and Women, Conditional on Household Education

\begin{tabular}{lrrrr} 
& 1940 & 1970 & 1980 & 1990 \\
\hline Men, Conditional on Low-Power & & & & \\
Non-metropolitan area & 0.331 & 0.237 & 0.138 & 0.123 \\
& $(0.015)$ & $(0.007)$ & $(0.007)$ & $(0.005)$ \\
Small metropolitan area & 0.288 & 0.378 & 0.388 & 0.394 \\
& $(0.016)$ & $(0.010)$ & $(0.009)$ & $(0.007)$ \\
Large metropolitan area & 0.378 & 0.384 & 0.384 & 0.484 \\
& $(0.019)$ & $(0.010)$ & $(0.009)$ & $(0.007)$ \\
Men, Conditional on Power & & & & \\
Non-metropolitan area & 0.237 & 0.194 & 0.115 & 0.088 \\
& $(0.029)$ & $(0.007)$ & $(0.005)$ & $(0.004)$ \\
Small metropolitan area & 0.307 & 0.392 & 0.397 & 0.397 \\
& $(0.034)$ & $(0.012)$ & $(0.009)$ & $(0.008)$ \\
Large metropolitan area & 0.456 & 0.415 & 0.488 & 0.515 \\
& $(0.042)$ & $(0.013)$ & $(0.011)$ & $(0.008)$ \\
Women, Conditional on Low-Power & & & & \\
Non-metropolitan area & 0.250 & 0.249 & 0.118 & 0.104 \\
& $(0.014)$ & $(0.007)$ & $(0.005)$ & $(0.004)$ \\
Small metropolitan area & 0.353 & 0.374 & 0.414 & 0.408 \\
& $(0.019)$ & $(0.011)$ & $(0.009)$ & $(0.007)$ \\
Large metropolitan area & 0.397 & 0.377 & 0.468 & 0.488 \\
& $(0.021)$ & $(0.011)$ & $(0.009)$ & $(0.007)$ \\
Women, Conditional on Power & & & & \\
Non-metropolitan area & 0.265 & 0.230 & 0.116 & 0.094 \\
& $(0.022)$ & $(0.009)$ & $(0.006)$ & $(0.004)$ \\
Small metropolitan area & 0.354 & 0.385 & 0.414 & 0.405 \\
& $(0.027)$ & $(0.013)$ & $(0.011)$ & $(0.008)$ \\
& 0.382 & 0.400 & 0.485 & 0.500 \\
& $(0.029)$ & $(0.014)$ & $(0.012)$ & $(0.008)$ \\
\hline & & & &
\end{tabular}

Note. All predictions are derived from a multinomial logit model and for white individuals who were 35 years old. Within each year for each household type the predicted probabilities should sum to one. 
We use our predicted locational choice probabilities for never married men and women and for power and low-power couples to estimate whether the increase in the proportion of power and low-power couples living in large metropolitan areas is greater than the increase in the probability that two individuals (one male and one female) coincidentally live in a large metropolitan area. That is, we estimate $\Delta_{90-40}^{P}-\Delta_{90-40}^{S P}$ and $\Delta_{90-40}^{L P}-\Delta_{90-40}^{S L P}$ where $S P$ and $S L P$ indicate the proportion of power singles and low-power singles, respectively, coincidentally living in a given city size. $\Delta_{90-40}^{S P}$ and $\Delta_{90-40}^{S L P}$ are estimated as

$$
\min \left(p_{90}^{M, P}, p_{90}^{F, P}\right)-\min \left(p_{40}^{M, P}, p_{40}^{F, P}\right)
$$

and

$$
\min \left(p_{90}^{M, L P}, p_{90}^{F, L P}\right)-\min \left(p_{40}^{M, L P}, p_{40}^{F, L P}\right)
$$

respectively, where $p$ indicates the probability that a power $(P)$ or low-power $(L P)$ never married man $(M)$ or woman $(F)$ lives in a large city. We take the minimum of the two probabilities because the smaller probability determines the proportion of coincidental power or low-power couples living in large cities. Thus if there are 100 single power men and women, then at most 100 couples could form. But, if 40 of the men are in large cities and 60 are in small cities whereas 60 of the women are in large cities and 40 are in small cities then the probability of observing a coincidental couple in a large city is only 0.4 and that of observing a coincidental couple in a small city is also only $0.4 .^{27}$

\footnotetext{
${ }^{27}$ Note that this method assumes that the numbers of single power men and single power women are the same, as are the numbers of single low-power men and single low-power women. Although this is a reasonable assumption in 1990, in 1940 there were more single unmarried power women because of the low marriage propensities of college educated women and there were more single low-power men because many single women did not live in their own households. However, when we formed coincidental couples based upon the numbers of men and women, our results
} 
If cities are increasingly becoming marriage markets, then the probability that a coincidental couple lives in a metropolitan area may be even greater than the probability that a power couple lives in a major metropolitan area. We therefore estimate the triple difference,

$$
\left[\Delta_{90-40}^{P}-\Delta_{90-40}^{S P}\right]-\left[\Delta_{90-40}^{L P}-\Delta_{90-40}^{S L P}\right]
$$

This triple difference will underestimate the extent to which large cities solve the colocation problem because an increasing fraction of singles will have to moved to large cities to preempt the colocation problem.

Table 8 shows that the increase in the predicted probability that two single individuals are in a large metropolitan area is 0.118 for power individuals and 0.106 for low-power individuals. In contrast, whereas the predicted concentration of power couples in cities has increased by 0.097 , that of low power couples has remained unchanged. Our results suggest that large cities are a magnet for all single people, regardless of education level and that therefore the triple not the double difference estimates the impact of the growing colocation problem on the concentration of power couples. Our triple difference yield an estimate of 0.086 , suggesting that 89 percent of the 0.097 predicted increase in the concentration of power couples in large cities between 1940 and 1990 can be explained by the colocation problem. Recall that our previous estimates using part power couples as a control group suggested that 52 to 62 percent of the increase in the proportion of power couples living in large cities could be attributed to the rising severity of the colocation problem. When we restrict ourselves to working couples, then the triple difference implies that 53 percent of the predicted increasing concentration of power couples in large cities is explained by changes in the extent of the colocation problem.

implied that by taking minimum probabilities we were underestimating the extent to which married couples move to larger cities because of the colocation problem. 
Table 8: Double and Triple Difference Estimates of Propensity to Live in Given Size City, 1940-1990, Using Marital Status as Control

\begin{tabular}{lrrr} 
& \multicolumn{3}{c}{ City Size } \\
& Large & Small & Non-metropolitan \\
\hline Power and Low-Power Couples & & & \\
$\Delta_{90-40}^{P}$ & 0.097 & 0.063 & -0.154 \\
$\Delta_{90-40}^{L P}$ & $(0.020)$ & $(0.020)$ & $(0.011)$ \\
& -0.001 & 0.069 & -0.097 \\
Coincidental Couples, & $(0.017)$ & $(0.015)$ & $(0.007)$ \\
Power and Low Power & & & \\
$\Delta_{90-40}^{S P}$ & & & -0.149 \\
& 0.118 & 0.090 & $(0.041)$ \\
$\Delta_{90-40}^{S L P}$ & $(0.037)$ & $(0.049)$ & -0.146 \\
& 0.106 & 0.106 & $(0.034)$ \\
Double Differences, Power & $(0.050)$ & $(0.030)$ & -0.005 \\
$\Delta_{90-40}^{P}-\Delta_{90-40}^{S P}$ & & & $(0.042)$ \\
Double Differences, Low Power & $(0.042)$ & $(0.053)$ & \\
$\Delta_{90-40}^{L P}-\Delta_{90-40}^{S L P}$ & & & -0.092 \\
Triple Differences & -0.107 & -0.037 & $(0.035)$ \\
{$\left[\Delta_{90-40}^{P}-\Delta_{90-40}^{S P}\right]-$} & $(0.053)$ & $(0.034)$ & \\
{$\left[\Delta_{90-40}^{L P}-\Delta_{90-40}^{S L P}\right]$} & & & 0.087 \\
& & & $(0.055)$ \\
\hline
\end{tabular}

Note. $\Delta_{90-40}^{P}$ and $\Delta_{90-40}^{L P}$ represent the change from 1940 to 1990 of the probability of being in a given sized city for power and low-power couples respectively. $\Delta_{90-40}^{S P}$ and $\Delta_{90-40}^{S L P}$ represent these probabilities for two power and low-power single individuals. This probability for two singles, for example, is the smaller of the probabilities of being in a given sized city for single power men and for single power women. Robust standard errors in parentheses. 
Although we have used 1940 as our starting point because our interest has been in long-run trends, we could use 1970 as a starting point as well. An advantage of doing so is that there will be less measurement error in our classifications of households by educational levels. ${ }^{28}$ Another advantage is that stratification on wife's labor force participation status is more reasonable because income and substitution effects were small (Goldin 1990: 119-158). When we use 1970 as a starting point, we find that when we compare working power with working part power couples the double difference estimate is very large $(0.178$ or 72 percent of the predicted increased concentration of power couples in large cities) whereas for couples in which the wife does not work the double difference estimate is negative (-0.056). Our resulting triple difference estimate (0.234) therefore more than explains the increased concentration of power couples in large cities between 1970 and 1990. When we compare working power couples with two single individuals our triple difference estimate is 0.137 suggesting that 57 percent of the predicted increased concentration of working power couples in large cities between 1970 and 1990 arises from the growing colocation problem. ${ }^{29}$

Thus far we have not explicitly considered the wife's occupation. But, a wife who has at least a college education and is in an occupation that was traditionally male, say law or medicine, is more likely to need the diversified labor market of a large city than a wife who is in such a traditionally female occupation as that of school teacher. Wage differences across city

\footnotetext{
${ }^{28}$ College graduation rates are overstated in the 1940 census in part because individuals who went to the preparatory department within a college were enumerated as having gone to college. We thank Claudia Goldin for pointing this out to us.

${ }^{29}$ Conditional on the wife not working power couples were more likely to move away from large cities than part-power couples from 1970 to 1990 . Thus the simple double difference estimate using part-power couples as a control group for power couples is only 0.012 or 16 percent of the increased concentration in power couples in large cities. Similarly, when all power couples, regardless of the wife's labor force participation status, are compared with two single individuals, the triple difference estimate is 0.028 or 38 percent of the increased concentration of power couples in large cities. Given that women have become more similar to men in terms of labor supply parameters (Goldin 1990: 119-158), it is more reasonable to stratify on labor force participation status in 1970 and 1990 than in 1940 and 1990.
} 
size in the non-profit sector may be smaller and may have grown more so over time. In the case of school teachers this may have been spurred by the move away from direct local funding to state and federal funding and the move towards collective bargaining agreements (Flyer and Rosen 1997). We therefore classify women's occupations as traditionally female if women were over-represented in these occupations relative to men in $1970 .{ }^{30}$ We then estimate a multinomial logit in which the categories of the dependent variable are all 15 combinations of 5 location sizes and of whether the wife is out of the labor force, the wife is in a traditional job, and the wife is in a non-traditional occupation. Aggregating all metropolitan areas in the top 50th percentile of the population distribution and all metropolitan areas in the bottom of the 50th percentile, the predicted probabilities for a white couple in which the husband is 35 years old are given in Table 9.

Table 9 shows that increases in the predicted concentration of power couples in large cities have been particularly sharp for those couples in which the wife is in a non-traditional occupation. The predicted proportion of power couples in which the wife works in a nontraditional occupation and who were in a large city increased from 2 percent in 1940 to 21 percent in 1990 but only from 2 to 13 percent among those in the smaller cities. However, for power couples in which the wife works in a traditional occupation the increase was from 6 to 15 percent in the larger metropolitan areas and from 3 to 15 percent in the smaller metropolitan areas. Among part-power couples the predicted proportion in the largest cities rose from 2 to 15 percent when wives were working in non-traditional occupations. The increase was from 4 to 12 percent when wives were working in traditional occupations. The increase in the smaller metropolitan areas was from 2 to 13 percent regardless of whether wives were working in traditional or

\footnotetext{
${ }^{30}$ These occupations include that of school teacher, librarian, nurse, social worker, and secretary. Although some laborers and operatives may have been in traditionally female laborer and operative occupations we cannot observe this and therefore do not classify any laborers or operatives as being in traditionally female occupations.
} 
Table 9: Predicted Probabilities of Locational Choice, Wife's Labor Force Participation Status (LFP), and Wife's Job Type Conditional on Household Education

\begin{tabular}{|c|c|c|c|c|}
\hline & 1940 & 1970 & 1980 & 1990 \\
\hline \multicolumn{5}{|l|}{ Conditional on Low Power } \\
\hline \multirow[t]{2}{*}{ Non-metropolitan area, $\mathrm{LFP}=0$} & 0.329 & 0.193 & 0.151 & 0.105 \\
\hline & $(0.003)$ & $(0.002)$ & $(0.002)$ & $(0.002)$ \\
\hline \multirow[t]{2}{*}{ Non-metropolitan area, LFP $=1$, Traditional Job $=1$} & 0.121 & 0.050 & 0.060 & 0.073 \\
\hline & $(0.001)$ & $(0.001)$ & $(0.001)$ & $(0.001)$ \\
\hline \multirow[t]{2}{*}{ Non-metropolitan area, $\mathrm{LFP}=1$, Traditional $\mathrm{Job}=0$} & 0.030 & 0.065 & 0.087 & 0.101 \\
\hline & $(0.001)$ & $(0.001)$ & $(0.002)$ & $(0.002)$ \\
\hline \multirow[t]{2}{*}{ Small metropolitan area, $\mathrm{LFP}=0$} & 0.251 & 0.208 & 0.171 & 0.130 \\
\hline & $(0.003)$ & $(0.002)$ & $(0.002)$ & $(0.002)$ \\
\hline \multirow[t]{2}{*}{ Small metropolitan area, LFP $=1$, Traditional Job $=1$} & 0.015 & 0.056 & 0.080 & 0.107 \\
\hline & $(0.001)$ & $(0.001)$ & $(0.001)$ & $(0.002)$ \\
\hline \multirow[t]{2}{*}{ Small metropolitan area, LFP $=1$, Traditional Job $=0$} & 0.030 & 0.062 & 0.102 & 0.144 \\
\hline & $(0.001)$ & $(0.001)$ & $(0.002)$ & $(0.002)$ \\
\hline \multirow[t]{2}{*}{ Large metropolitan area, $\mathrm{LFP}=0$} & 0.287 & 0.252 & 0.180 & 0.134 \\
\hline & $(0.003)$ & $(0.002)$ & $(0.002)$ & $(0.002)$ \\
\hline \multirow[t]{2}{*}{ Large metropolitan area, LFP $=1$, Traditional Job $=1$} & 0.017 & 0.054 & 0.075 & 0.088 \\
\hline & $(0.001)$ & $(0.001)$ & $(0.001)$ & $(0.001)$ \\
\hline \multirow[t]{2}{*}{ Large metropolitan area, LFP $=1$, Traditional Job $=0$} & 0.030 & 0.058 & 0.092 & 0.119 \\
\hline & $(0.001)$ & $(0.001)$ & $(0.001)$ & $(0.002)$ \\
\hline \multicolumn{5}{|l|}{ Conditional on Part-Power } \\
\hline \multirow[t]{2}{*}{ Non-metropolitan area, $\mathrm{LFP}=0$} & 0.259 & 0.157 & 0.091 & 0.054 \\
\hline & $(0.008)$ & $(0.002)$ & $(0.002)$ & $(0.002)$ \\
\hline \multirow[t]{2}{*}{ Non-metropolitan area, $\mathrm{LFP}=1$, Traditional $\mathrm{Job}=1$} & 0.024 & 0.054 & 0.070 & 0.073 \\
\hline & $(0.003)$ & $(0.002)$ & $(0.002)$ & $(0.002)$ \\
\hline \multirow[t]{2}{*}{ Non-metropolitan area, LFP $=1$, Traditional Job $=0$} & 0.147 & 0.031 & 0.048 & 0.056 \\
\hline & $(0.002)$ & $(0.001)$ & $(0.002)$ & $(0.002)$ \\
\hline \multirow[t]{2}{*}{ Small metropolitan area, $\mathrm{LFP}=0$} & 0.269 & 0.227 & 0.169 & 0.123 \\
\hline & $(0.009)$ & $(0.003)$ & $(0.003)$ & $(0.003)$ \\
\hline \multirow[t]{2}{*}{ Small metropolitan area, $\mathrm{LFP}=1$, Traditional Job $=1$} & 0.025 & 0.068 & 0.106 & 0.128 \\
\hline & $(0.003)$ & $(0.002)$ & $(0.003)$ & $(0.003)$ \\
\hline \multirow[t]{2}{*}{ Small metropolitan area, $\mathrm{LFP}=1$, Traditional Job $=0$} & 0.020 & 0.040 & 0.089 & 0.140 \\
\hline & $(0.003)$ & $(0.001)$ & $(0.002)$ & $(0.003)$ \\
\hline \multirow[t]{2}{*}{ Large metropolitan area, $\mathrm{LFP}=0$} & 0.330 & 0.306 & 0.209 & 0.154 \\
\hline & $(0.009)$ & $(0.003)$ & $(0.004)$ & $(0.003)$ \\
\hline \multirow[t]{2}{*}{ Large metropolitan area, LFP $=1$, Traditional Job $=1$} & 0.035 & 0.073 & 0.100 & 0.117 \\
\hline & $(0.004)$ & $(0.002)$ & $(0.003)$ & $(0.002)$ \\
\hline \multirow[t]{2}{*}{ Large metropolitan area, LFP $=1$, Traditional $\mathrm{Job}=0$} & 0.022 & 0.046 & 0.107 & 0.155 \\
\hline & $(0.003)$ & $(0.001)$ & $(0.003)$ & $(0.003)$ \\
\hline
\end{tabular}

\section{Continued}


Table 9: Predicted Probabilities of Locational Choice, Wife's Labor Force Participation Status (LFP), and Wife's Job Type (Continued)

\begin{tabular}{lrrrr} 
& 1940 & 1970 & 1980 & 1990 \\
\hline Conditional on Power & & & & \\
Non-metropolitan area, LFP=0 & 0.250 & 0.148 & 0.052 & 0.027 \\
Non-metropolitan area, LFP=1, Traditional Job=1 & $(0.001)$ & $(0.003)$ & $(0.002)$ & $(0.001)$ \\
& 0.035 & 0.060 & 0.092 & 0.069 \\
Non-metropolitan area, LFP=1, Traditional Job=0 & $(0.005)$ & $(0.002)$ & $(0.003)$ & $(0.002)$ \\
& 0.008 & 0.026 & 0.030 & 0.032 \\
Small metropolitan area, LFP=0 & $(0.002)$ & $(0.001)$ & $(0.001)$ & $(0.001)$ \\
& 0.257 & 0.215 & 0.129 & 0.095 \\
Small metropolitan area, LFP=1, Traditional Job=1 & $(0.012)$ & $(0.004)$ & $(0.003)$ & $(0.002)$ \\
& $(0.0032$ & 0.073 & 0.146 & 0.146 \\
Small metropolitan area, LFP=1, Traditional Job=0 & 0.016 & 0.038 & 0.080 & 0.131 \\
& $(0.003)$ & $(0.002)$ & $(0.002)$ & $(0.003)$ \\
Large metropolitan area, LFP=0 & 0.315 & 0.298 & 0.184 & 0.147 \\
& $(0.001)$ & $(0.004)$ & $(0.004)$ & $(0.003)$ \\
Large metropolitan area, LFP=1, Traditional Job=1 & 0.063 & 0.088 & 0.160 & 0.148 \\
& $(0.007)$ & $(0.003)$ & $(0.004)$ & $(0.003)$ \\
Large metropolitan area, LFP=1, Traditional Job=0 & 0.023 & 0.053 & 0.128 & 0.206 \\
& $(0.004)$ & $(0.002)$ & $(0.003)$ & $(0.004)$ \\
\hline
\end{tabular}

Note. All predictions are derived from a multinomial logit model and are for white couples in which the husband was 35 years old. Conditional on couple type, the columns should sum to one. 
non-traditional jobs. The double difference estimate for power relative to part-power wives in traditional occupations was 0.01 . In contrast, that of power relative to part-power wives in nontraditional occupations was 0.06 , suggesting that the growth of the colocation problem accounts for at least half of the increased concentration of power couples in large cities.

Recall that we predicted that for husbands and wives in the same occupation the couple may not need the diversified labor market offered by a large city because her best choice is his best choice. We tested whether for professionals the increase in the percentage of power couples is larger if the 3 digit census occupational category of the husband and wife differ by estimating a multinomial logit conditional on both husband and wife being professionals in which the dependent variable consisted of city size and occupational type cells. We found that in 1970, 1980, and 1990 the predicted proportion of husband and wives of the same occupation did not differ greatly by city size. It was a constant 9 percent in 1970 and in 1990 was 5 percent in the non-metropolitan areas and 9 percent in the metropolitan areas. But, the predicted proportion of husbands and wives of different occupations in 1970 was 18 percent in non-metropolitan areas and 31 percent in metropolitan areas. By 1990 these figures were 12 and 34 percent, suggesting that the diversified labor markets of large cities primarily solve the colocation problem of couples in different occupations.

We have shown that power couples are increasingly likely to locate in large cities relative to part-power couples or never married individuals and that this trend was particularly pronounced among power couples in which the wife was in a non-traditional occupation and among power couples in which the husband and wife were in different professional occupations. We argued that the rising colocation problem may account for about half of the increased migration of power couples to large metropolitan areas. Our analysis enables us to determine whether power couples are more likely to be in a larger relative to a smaller city and how this has changed over time, but not how many more power couples a city such as Buffalo would attract if its labor markets 
became more diverse but its climate did not change. To answer such a question we would need to estimate a structural model of city choice by household type. The data requirements of such an approach would be substantial, requiring us to specify for every city and every couple type the expected present value of searching in that labor market and the value of amenities. A common methodology for such an imputation is to assume a one factor model such that an individual in the top twentieth percentile of the wage distribution in one city is in the same percentile in another. Research on regional factor pricing disputes that one factor representations of earnings are valid (Heckman, Layne-Farrar, and Todd 1996; Heckman and Scheinkman 1987).

\section{Locational Choice: Monetary Incentives}

The incentives for power couples to move to large cities will diminish over time if their continued in-migration to large cities shifts out local labor supply along a stable demand curve. Increasing returns to scale models (such as Acemoglu (1996)) provide a microfoundation for models in which the demand for highly skilled workers increases with their numbers. ${ }^{31}$ Whether the increased migration of power couples to large cities has led to a decline in their relative wages is therefore an empirical issue. The higher rents of large cities will be a disincentive to migration.

We document the differential trend in wages for the high skilled by city size and the trend in rents by city size to provide some indication of how the returns to being in a large city are changing. We cannot observe how the expected present value of earnings net of rents has changed, but we can ascertain how education adjusted earnings by city size and rents by city size have changed over time and how they have changed for different household types (power,

\footnotetext{
${ }^{31}$ Acemoglu's (1996) search model shows that ex ante investment and bilateral search in the labor market will make the rate of return on human capital increasing in the average human capital of the workforce. In Becker and Murphy's (1992) model the greater density of urban areas lowers the costs of co-ordinating specialists.
} 
part-power, low-power). Even if all households were single in equilibrium wages could differ by city size within an educational group because an individual cannot simultaneously sell his skills to separate labor markets. ${ }^{32}$ Marriage creates bundles of bundles.

For every decade we therefore estimate wage regressions of the form

$$
\ln (w)=\beta_{0}+\beta_{1} \ln (d)+\beta_{2} C+\beta_{3}(C \times \ln (d))+\beta_{4} X+u
$$

where $w$ is the hourly wage in 1997 dollars, $d$ is population of the metropolitan area, $C$ is a dummy variable indicating that the individual has had at least 4 years of college, $X$ is a vector consisting of age, age squared, dummies indicating full time and part-time status, regional dummies, and a dummy indicating whether the household was in a non-metropolitan area, and $u$ is an error term. ${ }^{33}$ We restrict our sample to white households. Because for individuals in the government or non-profit sector, the spatial distribution of wages may be more compressed we estimate wage regressions for four different samples - all men earning a salary, all men who are neither in a government nor teaching job, all wage and salary women, and all women who are neither in a government, teaching, or such other traditionally female job as nurse or librarian. We also estimate how the husband and wife's combined wage and salary income has changed by decade by education and city size by estimating a regression of the form

$$
\ln (I)=\beta_{0}+\beta_{1} \ln (d)+\beta_{2} C+\beta_{4}(C \times \ln (d))+\beta_{4} X+u
$$

\footnotetext{
${ }^{32}$ For a model of skill bundling in which a law of one price for skills does not hold see Heckman and Scheinkman (1987) and Rosen (1983).

${ }^{33}$ Because we assumed that a mean sized city within a non-metropolitan area was equal in size to one half the size of the smallest city, we added a dummy variable controlling for non-metropolitan area. Our coefficients on population were similar in both our wage and rental regressions regardless of whether we excluded non-metropolitan areas. For the women we also estimated selection corrected wage regressions in 1980 and 1990. Because these yielded results similar to those obtained from ordinary least squares, we present the ordinary least squares results.
} 
where $I$ is their combined wage and salary income (the income of wives not in the labor force is set equal to 0$), d$ is the population of the metropolitan area, $C$ is a vector containing a dummy variable equal to one if the husband is college educated and another dummy variable if the wife is college educated, $X$ is a vector consisting of the age and age squared of the husband and of the wife and four dummies for their full-time and part-time status, as well as regional dummies, and a dummy indicating whether the household was in a non-metropolitan area, and an error term, $u$.

We establish how the costs, in terms of rents, of being in a large city have grown, by estimating for every decade, for all renters, both married and unmarried,

$$
\ln (r)=\beta_{0}+\beta_{1} \ln (d)+\beta_{2} X+u
$$

where $r$ is rent in 1997 dollars, $d$ is population of the metropolitan area, $X$ is a vector consisting of number of rooms (except for 1940 when this information is unavailable), regional dummies, and a dummy equal to one if the individual was in a non-metropolitan area, and $\mathrm{u}$ is an error term. ${ }^{34}$ We restrict the sample to renters because of the well-known systematic underreporting of house values by home owners (Goodman and Ittner 1992).

Before proceeding with the empirical analysis, we need to clarify the interpretation of our wage and rental regressions. The coefficient on metropolitan area population in the wage regression may be positive if it is proxying for productivity but negative if it is proxying for city amenities (Roback 1982; Rosen 1979). In the rental regression this coefficient will be positive both if it is proxying for greater productivity and amenities. The population coefficient in both the wage and rental regressions may change from decade to decade as the growing concentration of power couples in large cities raises rents and lowers wages. Ideally our regressions would

\footnotetext{
${ }^{34}$ The omission of rooms in 1970, 1980, and 1990 did not affect the coefficient on metropolitan population, suggesting that the omission of this variable in 1940 will not bias the results.
} 
yield reliable estimates of the costs and benefits to living in large cities for different types of households, but we recognize that there may be sorting on unobservable skills (Glaeser and Mare, forthcoming). ${ }^{35}$

Tables 10 and 11 present predicted hourly wage differentials by city size from our wage regressions for 35 year olds working full time and full year and living within the mean sized large, small, and non-metropolitan city in a given year. Our predicted wage differentials show that for men in all occupations the returns to city size have increased more sharply for college-educated than for non-college educated men. When men in government and teaching jobs are excluded from the sample, the differential returns to education in city size of the college-educated are only slightly higher. Among all women those without a college education in 1970 through 1990 obtain a higher differential return to larger cities than those with a college education, largely because rural areas contain many women in such traditionally female occupations as teaching who are paid as well as their larger city counterparts. When women in government jobs and in traditionally female occupations are excluded from the sample Table 11 shows that the returns to city size have increased more for the college educated than for the non-college educated. Our results suggest that for a power couple in which the wife is in a non-traditional occupation, the returns to being in a large city have more than doubled, whereas for a low power couple the increase has been somewhat smaller. Differentials in combined annual income also suggest that the returns to power couples of being in large relative to small cities or to non-metropolitan areas have grown more than the returns to part-power and low-power couples (see Table 12).

Table 13 presents monthly rent differentials by city size predicted from our rental regres-

\footnotetext{
${ }^{35}$ One possible interpretation of our wage regressions is that they yield a measure of the cost of being the tied mover or stayer. Ofek and Merrill (1997) showed that within a single year wives' returns to education in large cities were relatively higher than those of their husbands', suggesting that the size of the tie is larger in smaller cities. Frank (1978b) showed that this was true for couples who had recently migrated. When we run a specification similar to that of Ofek and Merrill (1997), our results suggest that women in non-traditional occupations obtain higher returns than men to being in a large city, but that this return has fluctuated since 1940.
} 
Table 10: Predicted Hourly Wage Differentials (in 1997 \$) for Married Men by City Size and Educational Status, 1940-1990

\begin{tabular}{|c|c|c|c|c|c|c|}
\hline & \multicolumn{3}{|c|}{$\begin{array}{l}\text { Not College Educated } \\
\text { City Size Differentials }\end{array}$} & \multicolumn{3}{|c|}{$\begin{array}{c}\text { College Educated } \\
\text { City Size Differentials }\end{array}$} \\
\hline & $\begin{array}{l}\text { Large- } \\
\text { Small }\end{array}$ & $\begin{array}{l}\text { Small- } \\
\text { Nonmetro- } \\
\text { politan }\end{array}$ & $\begin{array}{l}\text { Large- } \\
\text { Nonmetro- } \\
\text { politan }\end{array}$ & $\begin{array}{l}\text { Large- } \\
\text { Small }\end{array}$ & $\begin{array}{c}\text { Small- } \\
\text { Nonmetro- } \\
\text { politan }\end{array}$ & $\begin{array}{c}\text { Large- } \\
\text { Nonmetro- } \\
\text { politan }\end{array}$ \\
\hline \multicolumn{7}{|l|}{ All } \\
\hline \multirow[t]{2}{*}{1940} & 0.56 & 1.22 & 1.78 & 0.27 & 1.22 & 1.49 \\
\hline & $(0.04)$ & $(0.02)$ & $(0.03)$ & $(0.11)$ & $(0.14)$ & $(0.14)$ \\
\hline \multirow[t]{2}{*}{1970} & 1.40 & 1.73 & 3.13 & 1.99 & 2.39 & 4.38 \\
\hline & $(0.05)$ & $(0.07)$ & $(0.08)$ & $(0.16)$ & $(0.24)$ & $(0.28)$ \\
\hline \multirow[t]{2}{*}{1980} & 1.11 & 1.17 & 2.28 & 2.09 & 2.03 & 4.12 \\
\hline & $(0.03)$ & $(0.03)$ & $(0.06)$ & $(0.04)$ & $(0.04)$ & $(0.10)$ \\
\hline \multirow[t]{2}{*}{1990} & 2.14 & 1.41 & 3.55 & 3.65 & 2.55 & 6.20 \\
\hline & $(0.03)$ & $(0.02)$ & $(0.03)$ & $(0.08)$ & $(0.03)$ & $(0.09)$ \\
\hline \multirow[t]{2}{*}{$\Delta_{90-40}$} & 1.58 & 0.19 & 1.77 & 3.38 & 1.33 & 4.71 \\
\hline & $(0.05)$ & $(0.03)$ & $(0.04)$ & $(0.14)$ & $(0.14)$ & $(0.17)$ \\
\hline \multicolumn{7}{|c|}{ Restricted } \\
\hline \multirow[t]{2}{*}{1940} & 0.27 & 1.22 & 1.49 & 0.34 & 1.28 & 1.62 \\
\hline & $(0.03)$ & $(0.02)$ & $(0.02)$ & $(0.12)$ & $(0.17)$ & $(0.17)$ \\
\hline \multirow[t]{2}{*}{1970} & 1.99 & 2.39 & 4.38 & 1.90 & 2.32 & 4.27 \\
\hline & $(0.07)$ & $(0.07)$ & $(0.08)$ & $(0.33)$ & $(0.11)$ & $(0.37)$ \\
\hline \multirow[t]{2}{*}{1980} & 2.09 & 2.03 & 4.12 & 2.13 & 2.15 & 4.28 \\
\hline & $(0.05)$ & $(0.03)$ & $(0.06)$ & $(0.11)$ & $(0.06)$ & $(0.11)$ \\
\hline \multirow[t]{2}{*}{1990} & 3.65 & 2.55 & 6.20 & 3.91 & 2.66 & 6.57 \\
\hline & $(0.02)$ & $(0.01)$ & $(0.03)$ & $(0.04)$ & $(0.04)$ & $(0.09)$ \\
\hline \multirow[t]{2}{*}{$\Delta_{90-40}$} & 3.38 & 1.33 & 4.71 & 3.57 & 1.38 & 4.95 \\
\hline & $(0.04)$ & $(0.02)$ & $(0.04)$ & $(0.13)$ & $(0.17)$ & $(0.19)$ \\
\hline
\end{tabular}

Note. All values were predicted from a regression of the logarithm of wages on the logarithm of population size, a dummy equal to one if the individual was college-educated, the interaction between this dummy and population size, age, age squared, dummies indicating full time and part-year status, regional dummies, and a dummy indicating whether the household was in a non-metropolitan area. Predicted values are for individuals aged 35 working full-time and full-year and living within the mean sized large, small, and non-metropolitan area in each year. Regional dummies were set equal to their mean values within each year. The restricted sample excludes men in government and teaching jobs. Robust standard errors in parentheses. 
Table 11: Predicted Hourly Wage Differentials (in 1997 \$) for Married Women by City Size and by Educational Status, 1940-1990

\begin{tabular}{|c|c|c|c|c|c|c|}
\hline & \multicolumn{3}{|c|}{$\begin{array}{l}\text { Not College Educated } \\
\text { City Size Differentials }\end{array}$} & \multicolumn{3}{|c|}{$\begin{array}{c}\text { College Educated } \\
\text { City Size Differentials }\end{array}$} \\
\hline & $\begin{array}{l}\text { Large- } \\
\text { Small }\end{array}$ & $\begin{array}{l}\text { Small- } \\
\text { Nonmetro- } \\
\text { politan }\end{array}$ & $\begin{array}{c}\text { Large- } \\
\text { Nonmetro- } \\
\text { politan }\end{array}$ & $\begin{array}{l}\text { Large- } \\
\text { Small }\end{array}$ & $\begin{array}{l}\text { Small- } \\
\text { Nonmetro- } \\
\text { politan }\end{array}$ & $\begin{array}{c}\text { Large- } \\
\text { Nonmetro- } \\
\text { politan }\end{array}$ \\
\hline \multicolumn{7}{|l|}{ All } \\
\hline \multirow[t]{2}{*}{1940} & 0.92 & 0.98 & 1.9 & 1.64 & 1.63 & 3.27 \\
\hline & $(0.02)$ & $(0.02)$ & $(0.03)$ & $(0.17)$ & $(0.16)$ & $(0.20)$ \\
\hline \multirow[t]{2}{*}{1970} & 1.03 & 0.89 & 1.92 & 0.96 & 0.89 & 1.85 \\
\hline & $(0.02)$ & $(0.02)$ & $(0.02)$ & $(0.06)$ & $(0.09)$ & $(0.18)$ \\
\hline \multirow[t]{2}{*}{1980} & 0.94 & 0.67 & 1.61 & 0.92 & 0.59 & 1.51 \\
\hline & $(0.01)$ & $(0.00)$ & $(0.01)$ & $(0.02)$ & $(0.02)$ & $(0.04)$ \\
\hline \multirow[t]{2}{*}{1990} & 1.68 & 1.27 & 2.95 & 2.11 & 1.55 & 3.66 \\
\hline & $(0.01)$ & $(0.00)$ & $(0.01)$ & $(0.04)$ & $(0.04)$ & $(0.10)$ \\
\hline \multirow[t]{2}{*}{$\Delta_{90-40}$} & 0.76 & 0.29 & 1.05 & 0.47 & -0.08 & 0.39 \\
\hline & $(0.02)$ & $(0.02)$ & $(0.03)$ & $(0.17)$ & $(0.17)$ & $(0.22)$ \\
\hline \multicolumn{7}{|c|}{ Restricted } \\
\hline \multirow[t]{2}{*}{1940} & 0.47 & 0.82 & 1.29 & 0.63 & 1.09 & 1.72 \\
\hline & $(0.07)$ & $(0.07)$ & $(0.07)$ & $(0.42)$ & $(0.84)$ & $(0.81)$ \\
\hline \multirow[t]{2}{*}{1970} & 1.05 & 0.89 & 1.94 & 1.15 & 1.02 & 2.17 \\
\hline & $(0.03)$ & $(0.03)$ & $(0.04)$ & 1.95 & 1.35 & 3.30 \\
\hline \multirow[t]{2}{*}{1980} & 1.10 & 0.72 & 1.82 & 1.95 & 1.35 & 3.30 \\
\hline & $(0.01)$ & $(0.01)$ & $(0.02)$ & $(0.04)$ & $(0.07)$ & $(0.07)$ \\
\hline \multirow[t]{2}{*}{1990} & 1.94 & 1.39 & 3.33 & 3.28 & 2.37 & 5.65 \\
\hline & $(0.02)$ & $(0.01)$ & $(0.02)$ & $(0.08)$ & $(0.05)$ & $(0.09)$ \\
\hline \multirow[t]{2}{*}{$\Delta_{90-40}$} & 1.47 & 0.57 & 2.04 & 2.65 & 1.31 & 3.93 \\
\hline & $(0.07)$ & $(0.07)$ & $(0.07)$ & $(0.43)$ & $(0.84)$ & $(0.81)$ \\
\hline
\end{tabular}

Note. All values were predicted from a regression of the logarithm of wages on the logarithm of population size, a dummy equal to one if the individual was college-educated, the interaction between this dummy and population size, age, age squared, dummies indicating full time and part-time status, regional dummies, and a dummy indicating whether the household was in a non-metropolitan area. Predicted values are for individuals aged 35 working full-time and full-year and living within the mean sized large, small, and non-metropolitan area in each year. Regional dummies were set equal to their mean values within each year. The restricted sample excludes women in government and teaching jobs and traditional female occupations. Robust standard errors in parentheses. 
Table 12: Predicted Differences in Combined Annual Income (in 1997 \$) Across City Size

City Size Income Differentials

\begin{tabular}{|c|c|c|c|}
\hline & $\begin{array}{l}\text { Large- } \\
\text { Small }\end{array}$ & $\begin{array}{l}\text { Small- } \\
\text { Nonmetro- } \\
\text { politan }\end{array}$ & $\begin{array}{c}\text { Large- } \\
\text { Nonmetro- } \\
\text { politan }\end{array}$ \\
\hline \multicolumn{4}{|c|}{ Conditional on Low-power } \\
\hline \multirow[t]{2}{*}{1940} & 2,618 & 4,106 & 6,724 \\
\hline & $(881)$ & $(761)$ & $(884)$ \\
\hline \multirow[t]{2}{*}{1970} & 3,809 & 4,497 & 8,307 \\
\hline & $(783)$ & $(702)$ & $(863)$ \\
\hline \multirow[t]{2}{*}{1980} & 4,432 & 3,880 & 8,312 \\
\hline & $(772)$ & $(657)$ & $(877)$ \\
\hline \multirow[t]{2}{*}{1990} & 9,037 & 6,083 & 15,120 \\
\hline & $(612)$ & $(520)$ & $(645)$ \\
\hline \multirow[t]{2}{*}{$\Delta_{90-40}$} & 6,419 & 1,977 & 8,396 \\
\hline & $(1,073)$ & $(922)$ & $(1,094)$ \\
\hline \multicolumn{4}{|c|}{ Conditional on Part-power } \\
\hline \multirow[t]{2}{*}{1940} & 598 & 575 & 1,174 \\
\hline & $(1,474)$ & $(1,454)$ & $(1,652)$ \\
\hline \multirow[t]{2}{*}{1970} & 4,952 & 4,163 & 9,116 \\
\hline & $(1,389)$ & $(1,300)$ & $(1,492)$ \\
\hline \multirow[t]{2}{*}{1980} & 7,419 & 6,755 & 14,174 \\
\hline & $(1,639)$ & $(973)$ & $(1,546)$ \\
\hline \multirow[t]{2}{*}{1990} & 14,187 & 12,635 & 21,664 \\
\hline & $(1,909)$ & (997) & $(1,799)$ \\
\hline \multirow[t]{2}{*}{$\Delta_{90-40}$} & 13,589 & 12,060 & 20,490 \\
\hline & $(2,412)$ & $(4,281)$ & $(2,442)$ \\
\hline \multicolumn{4}{|c|}{ Conditional on Power } \\
\hline \multirow[t]{2}{*}{1940} & 852 & 7,028 & 7,880 \\
\hline & $(1,877)$ & $(2,019)$ & $(1,877)$ \\
\hline \multirow[t]{2}{*}{1970} & 5,783 & 5,723 & 11,506 \\
\hline & $(2,162)$ & $(1,186)$ & $(2,026)$ \\
\hline \multirow[t]{2}{*}{1980} & 8,324 & 6,016 & 14,339 \\
\hline & $(1,506)$ & $(1,280)$ & $(2,741)$ \\
\hline \multirow[t]{2}{*}{1990} & 16,383 & 10,871 & 27,254 \\
\hline & $(1,767)$ & $(1,260)$ & $(1,704)$ \\
\hline \multirow[t]{2}{*}{$\Delta_{90-40}$} & 15,531 & 3,843 & 19,374 \\
\hline & $(2,578)$ & $(2,380)$ & $(2,535)$ \\
\hline
\end{tabular}

Note. All values were predicted from a regression of the logarithm of wages on the logarithm of population size, a dummy equal to one if the individual was college-educated, the interaction between this dummy and population size, age, age squared, dummies indicating full time and part-time status, regional dummies, and a dummy indicating whether the household was in a non-metropolitan area. Predicted values are for individuals aged 35 working full-time and full-year and living within the mean sized large, small, and non-metropolitan area in each year. Regional dummies were set equal to their mean values within each year. Robust standard errors in parentheses. 
Table 13: Predicted Monthly Differences in Rental Values (in 1997 \$) Across City Size

\begin{tabular}{rrrr} 
& \multicolumn{3}{c}{ City Size Rent Differentials } \\
& $\begin{array}{c}\text { Large- } \\
\text { Small }\end{array}$ & $\begin{array}{c}\text { Small- } \\
\text { Nonmetro- } \\
\text { politan }\end{array}$ & $\begin{array}{c}\text { Large- } \\
\text { Nonmetro- } \\
\text { politan }\end{array}$ \\
\hline 1940 & 63.43 & 96.38 & 159.81 \\
& $(12.51)$ & $(5.91)$ & $(11.90)$ \\
1970 & 76.86 & 92.64 & 169.50 \\
& $(18.08)$ & $(11.03)$ & $(15.79)$ \\
1980 & 85.80 & 134.60 & 220.40 \\
& $(15.91)$ & $(6.01)$ & $(14.88)$ \\
1990 & 151.21 & 165.95 & 317.16 \\
& $(18.22)$ & $(6.71)$ & $(17.08)$ \\
\hline
\end{tabular}

Note. Predictions are from yearly rental regressions holding constant within each year the number of rooms and the region dummies at the mean values of that year. Robust standard errors in parentheses.

sions for mean-sized cities within large and small metropolitan areas and for non-metropolitan areas, holding constant within each year the number of rooms and the region dummies at the mean values of that year. Rents in large cities were 1.7 times higher in 1990 than in 1940 but in small metropolitan areas were only 1.5 times higher and in non-metropolitan areas 1.3 times higher. Because power, part-power, and low-power couples face the same rents but the wage incentives to power couples of being in a large city increased by more, our results suggest that cities have become relatively more attractive to power couples than to part-power or low-power couples. The smaller rental increases in small cities and non-metropolitan areas have given part-power and low-power couples a relative advantage.

The predictions from combined annual wage and salary regressions can be used to illustrate the impact of the move away from non-metropolitan areas on household income inequality. The difference between power and low-power couples in combined annual wage and salary income (in 1997 ) in 1940 was $\$ 17,092$ in large cities, $\$ 18,858$ in small cities, and $\$ 15,936$ in non-metropolitan areas. In 1990 these respective differences were $\$ 35,376, \$ 28,030$, 
and $\$ 23,242$. The move away from non-metropolitan areas and the concomitant increase in the labor force participation rate of power wives in large cities has increased inequality both across city size within a given decade and within large cities across decades.

\section{Universities and City Size}

Our finding that since 1940 power couples have been increasingly likely to locate in large metropolitan areas and that the growth of the colocation problem accounts for much of this trend has implications for city growth. Because of the bundling problem firms in smaller cities may find that it is becoming harder and harder to attract highly skilled individuals. We illustrate the difficulties faced by firms in small cities with suggestive evidence on a particular type of firm the university. One advantage of examining universities is that their capital to labor ratio is fairly fixed. Another is that universities, unlike firms, rarely move. We therefore examine whether the relative quality of graduate research doctorate programs in small cities in the United States has fallen since 1970 to learn whether a firm that employs highly skilled workers is now less likely to locate to a small city.

We use the National Research Council's dataset, Research Doctorate Programs in the United States, to obtain rankings of 1,142 graduate programs of 100 universities in 1993, 1983, and 1970 and we link these data to metropolitan area population. (We use the same metropolitan areas as in our previous empirical work.) We classify all programs into quintiles: distinguised, strong, good, adequate, and marginal. We then estimate an ordered probit model in which the dependent variable consists of a categorical variable for our five groups and in which the independent variables are the logarithm of metropolitan area population, dummy variables for broad program field (arts and humanities, biological sciences, engineering, physical sciences and mathematics, and social and behavioral sciences), and a dummy variable equal to one if the 
Table 14: Derivatives of Probability that Graduate School Program is Distinguished, Strong, Good, Adequate, and Marginal With Respect to Logarithm of City Population, 1993, 1983, and 1970

\begin{tabular}{lrrr} 
& \multicolumn{3}{c}{ Derivative wrt } \\
& \multicolumn{1}{c}{ Logarithm of City Population } \\
& 1970 & 1983 & \multicolumn{1}{c}{1993} \\
\hline Mean of Logarithm of Population & 7.075 & 7.547 & 7.673 \\
Probability & & & \\
Distinguished (Top Quintile) & 0.007 & 0.024 & 0.027 \\
& $(0.007)$ & $(0.008)$ & $(0.009)$ \\
Strong & 0.007 & 0.013 & 0.007 \\
& $(0.006)$ & $(0.004)$ & $(0.003)$ \\
Good & -0.000 & -0.006 & -0.011 \\
& $(0.001)$ & $(0.003)$ & $(0.004)$ \\
Adequate & -0.005 & -0.016 & -0.017 \\
& $(0.005)$ & $(0.006)$ & $(0.006)$ \\
Marginal (Bottom Quintile) & -0.010 & -0.027 & -0.027 \\
& $(0.013)$ & $(0.019)$ & $(0.020)$ \\
\hline
\end{tabular}

Note. 1142 observations in all years. Population is in the 1000s. Derivatives are estimated from an ordered probit model (see text for estimation details). Standard errors are in parentheses. We rejected the hypothesis that 1970 and 1993 and 1970 and 1983 should be pooled.

university was a public institution.

Table 14 presents the derivatives with respect to the logarithm of metropolitan area population from the ordered probit model. Note that the relationship between graduate program ranking and population size is stronger in 1993 than in 1970. In 1970 an increase of one in the logarithm of population increased the probability that a program would be ranked distinguished by 0.007 and decreased the probability that it would be ranked marginal by 0.010 . The respective figures for 1993 were 0.027 and 0.027 . The relative decline in quality of universities in small cities suggests that if there are spillover effects from universities larger rather than smaller cities are more likely to reap these benefits. 


\section{Implications}

This paper has documented the rising concentration of power couples in larger over smaller metropolitan areas and over non-metropolitan areas relative to other household types and to that which would have been predicted for two observationally identical single individuals. We estimated that about half of the increased concentration of power couples in larger metropolitan areas could be explained by the colocation problem. We also showed that the wage incentives of being in a large city have increased since 1940 and that this increase has been particularly large for college educated men and for college-educated women in non-traditional occupations. We showed that the disincentives of being in a large city, in terms of rents, have increased as well. Because rent increases have been smaller in small cities and in non-metropolitan areas households other than power couples have a relative advantage in these locations.

An outcome of the increased concentration of power couples in large cities has been to increase household income inequality. Because large cities solve the colocation problem, wives are more likely to work in large cities because their labor commands a higher wage. In fact, in 1990 household income inequality was greater in metropolitan than in non-metropolitan areas.

The increased concentration of power couples in large metropolitan areas may have implications for the dynamics of city growth. Economic growth depends upon the ability to absorb existing knowledge and to create new knowledge, both of which are directly related to the existing stock of human capital. Smaller markets have always exported the highly skilled to larger markets and, as this paper has documented, this phenomenon has been magnified by the increased bundling of the highly skilled with other highly skilled spouses. Cities, especially low amenity cities, may face a greater net "brain drain" than in the absence of power couple bundling. The colocation problem may also affect a small city's adjustment to local labor market shocks. Regional adjustment to local labor market shocks is primarily driven by labor mobility (Blanchard 
and Katz (1992)). But, because of bundling a small city may only slowly attract high skilled talent despite a local boom. Forseeing this, firms may be unwilling to locate in smaller cities. Universities provide suggestive evidence. We have shown that although the quality of graduate doctoral programs was positively related to city size in both 1970 and in 1993, the relationship between program ranking and city size has become stronger.

This paper has sketched a 50 year trend in power couple locational choice, but will information technology affect future locational choice? It is possible that the growth of information technology that permits highly skilled workers to telecommute may solve the colocation problem for some couples by permitting at least one spouse to live far from where their employer is located. This could allow smaller cities to attract a highly skilled couple. But, as more power couples become true dual career households, an increasing proportion of power couples will be faced with a colocation problem and the 50 year trend suggests that they will turn to large cities. Furthermore, information technologies may be a complement, not a substitute, for living in a large city if they facilitate making new business contacts (Gaspar and Glaeser 1998). Power couples are likely to have a comparative advantage in making new contacts relative to two highly educated single people. Although this paper has not explicitly explored the couple "synergies" of two highly educated people being married, a power couple may work as a "team" to maximize household income. They will therefore both seek potential business contacts who can work with them or their spouse and such contacts are more likely to be found in large cities.

\section{References}

[1] Acemoglu, Daron. 1996. "A Microfoundation for Social Increasing Returns in Human Capital Accumulation." Quarterly Journal of Economics. 111(3, August): 779-804.

[2] Baumgardner, James R. 1988. "Physicians' Services and the Division of Labor Across Markets." The Journal of Political Economy. 96(5, October): 948-982. 
[3] Becker, Gary S. 1991. A Treatise on the Family (Enlarged Edition). Cambridge, MA: Harvard University Press.

[4] Becker, Gary S. and Kevin M. Murphy. 1992. "The Division of Labor, Coordination Costs, and Knowledge." The Quarterly Journal of Economics. 107(4, November): 1137-1160.

[5] Blanchard, Olivier Jean and Lawrence F. Katz. 1992. "Regional Evolutions." Brookings Papers on Economic Activity.

[6] Blomquist, Glenn C., Mark C. Berger, and John P. Hoehn. 1988. "New Estimates of Quality of Life in Urban Areas." The American Economic Review. 78(1, March): 89-107.

[7] Brueckner, Jan K. and David A. Fansler. 1983. "The Economics of Urban Sprawl: Theory and Evidence on the Spatial Sizes of Cities." Review of Economics and Statistics. 65(3, August 1983): 479-82.

[8] Flyer, Frederick and Sherwin Rosen. 1997. "The New Economics of Teachers and Education.” Journal of Labor Economics. 15(1, Part 2, January): S104-39.

[9] Frank, Robert. 1978a. "Family Location Constraints and the Geographic Distribution of Female Professionals." Journal of Political Economy. 86(1, February): 117-30.

[10] Frank, Robert. 1978b. "Why Women Earn Less: The Theory and Estimation of Differential Overqualification." American Economic Review. 68(3, June): 360-73.

[11] Gaspar, Jess and Edward L. Glaeser. 1998. "Information Technology and the Future of Cities.” Journal of Urban Economics. 43(1, January): 136-56.

[12] Glaeser, Edward L. 1998. "Are Cities Dying?” Journal of Economic Perspectives. 12(2, Spring): 139-160.

[13] Glaeser, Edward L. and David C. Mare. Forthcoming. "Cities and Skills." Journal of Labor Economics.

[14] Glaeser, Edward L., Scheinkman, Jose A., Shleifer, Andrei. 1995. "Economic Growth in a Cross-Section of Cities." Journal of Monetary Economics. 36(1, December): 117-43.

[15] Goldin, Claudia. 1990. Understanding the Gender Gap: An Economic History of American Women. New York-Oxford: Oxford University Press.

[16] Goldin, Claudia. 1992. "The Meaning of College in the Lives of American Women: The Past One-Hundred Years." National Bureau of Economic Research Working Paper No. 4099 (June), Cambridge, MA.

[17] Goldin, Claudia. 1997. "Career and Family: College Women Look to the Past." In F. Blau and R. Ehrenberg, Eds, Gender and Family Issues in the Workplace. New York: Russell Sage. 
[18] Goodman, John L Jr. and John B. Ittner. 1992. "The Accuracy of Home Owners' Estimates of House Value." Journal of Housing Economics. 2(4): 339-57.

[19] Gyourko, Joseph, Tracy, Joseph. 1991. "The Structure of Local Public Finance and the Quality of Life.” Journal of Political Economy. 99(4, August): 774-806.

[20] Heckman, James, Anne Layne-Farrar, and Petra Todd. 1996. "Human Capital Pricing Equations with an Application to Estimating the Effect of Schooling Quality on Earnings." Review of Economics and Statistics. 78(4, November): 562-610.

[21] Heckman, James and Jose Scheinkman. 1987. "The Importance of Bundling in a GormanLancaster Model of Earnings." Review of Economic Studies. 54(2, April): 243-55.

[22] Hofferth, Sandra L. and Douglas A. Wissoker. 1992. "Price, Quality, and Income in Child Care Choices.” Journal of Human Resources. 27(1, Winter): 70-111.

[23] Jaeger, David A., Susanna Loeb, Sarah E. Turner, and John Bound. 1998. "Coding Geographic Areas Across Census Years: Creating Consistent Definitions of Metropolitan Areas." National Bureau of Economic Research Working Paper No. 6772, Cambridge MA.

[24] Juhn, Chinhui and Kevin M. Murphy. 1997. "Wage Inequality and Family Labor Supply." Journal of Labor Economics. 15(1, January), Pt. 1: 72-97.

[25] Kahn, Matthew E. 1997. "Particulate Pollution Trends in the United States." Regional Science and Urban Economics. 27(1, February): 87-107.

[26] Kim, Sunwoong. 1989. "Labor Specialization and the Extent of the Market.” The Journal of Political Economy. 97(3, June): 692-705.

[27] Lucas, Robert E., Jr. 1988. "On the Mechanics of Economic Development." Journal of Monetary Economics. 22(1, July): 3-42.

[28] Mare, Robert D. 1991. "Five Decades of Educational Assortative Mating." American Sociological Review. 56(1, February): 15-32.

[29] Marwell, Gerald, Rachel Rosenfeld, and Seymour Spilerman. 1979. "Geographic Constraints on Women's Careers in Academia.” Science. 205(21, September): 1225-1231.

[30] Mincer, Jacob. 1962. "Labor Force Participation of Married Women: A Study of Labor Supply." In Aspects of Labor Economics. Universities-National Bureau Committee for Economic Research. Princeton, NJ: Princeton University Press.

[31] Mincer, Jacob. 1978. "Family Migration Decisions." Journal of Political Economy. 86(7, October): 749-73.

[32] Ofek, Haim and Yesook Merrill. 1997. "Labor Immobility and the Formation of Gender Wage Gaps in Local Markets.” Economic Inquiry. 35(1, January): 28-47. 
[33] Pencavel, John. 1998. "Assortative Mating by Schooling and the Work Behavior of Wives and Husbands." American Economic Review. 88(2, May): 326-29.

[34] Rauch, James E. 1993. "Productivity Gains from Geographic Concentration of Human Capital: Evidence from the Cities." Journal of Urban Economics. 34(3, November): 380400 .

[35] Roback, Jennifer. 1982. "Wages, Rents, and the Quality of Life." Journal of Political Economy. 90(6, December): 1257-78.

[36] Rosen, Sherwin. 1979. "Wage-based Indexes of Urban Quality of Life." In Peter Mieszkowski and Mahlon Straszheim, Eds, Current Issues in Urban Economics. Baltimore, MD: Johns Hopkins University Press.

[37] Rosen, Sherwin. 1983. "A Note on Aggregation of Skills and Labor Quality [Linear Synthesis of Skill Distribution]." Journal of Human Resources. 18(3, Summer): 425-31.

[38] Ruggles, Steven and Matthew Sobek. 1995. Integrated Public Use Microdata Series, IPUMS95 Version 1.0. Social History Research Laboratory. Minneapolis, MN: Department of History. University of Minnesota. http://www.hist.umn.edu/ ipums/.

[39] Simon, Curtis. 1998. "Human Capital and Metropolitan Employment Growth.” Journal of Urban Economics. 43: 223-243.

[40] Sjaastad, Larry A. 1962. "The Costs and Returns of Human Migration.” Journal of Political Economy. 70(5, October): 80-93.

[41] Topel, Robert H. and Sherwin Rosen. 1988. "Housing Investment in the United States" Journal of Political Economy. 96(4, August): 718-40.

[42] Topel, Robert H. and Michael P. Ward. 1992. "Job Mobility and the Careers of Young Men." Quarterly Journal of Economics. 107(2, May): 439-479.

[43] Weiss, Yoram. 1997. "The Formation and Dissolution of Families: Why Marry? Who Marries Whom? And What Happens Upon Divorce." In Mark R. Rosenzweig and Oded Stark, Eds., Handbook of Population and Family Economics. Amsterdam: Elselvier. 